\title{
Using Cheap Talk to Polarize or Unify a Group of Decision Makers
}

\author{
Daeyoung Jeong*
}

The views expressed herein are those of the authors and do not necessarily reflect the official views of the Bank of Korea. When reporting or citing this paper, the authors' names should always be explicitly stated.

* Economic Research Institute, The Bank of Korea, Tel: +82-2-759-5430, Email: daeyoung.jeong@gmail.com.

For helpful comments, I thank James Peck, Lixin Ye, Huanxing Yang, Yaron Azrieli, Paul J. Healy, Daeho Kim, Navin Kartik, Timofiy Mylovanov, Thomas Palfrey, Heikki Rantakari, Ettore Damiano, Jack Fanning, Johanna Mollerstrom, Alexander L. Brown, Alexey Kushnir, Emmanuelle Walkowiak, Fei Li, Semin Kim, Sanghyun Kim, Yeochang Yoon, Anthony Bradfield, Sangjun Yea, Wook Sohn, Jong Ku Kang, Hwan-Koo Kang, Jieun Lee, Euncheol Shin. 


\section{Contents}

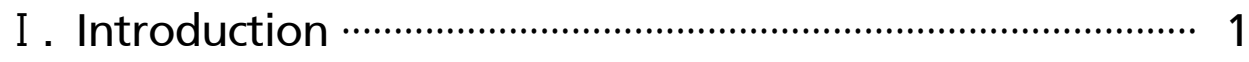

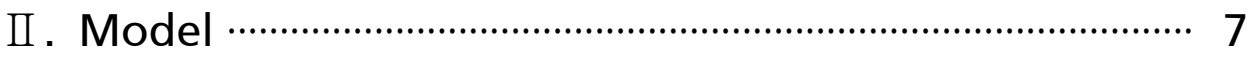

III. Highly Biased Expert …………………………………..... 14

IV. Surplus Maximizing Expert ………………………....... 20

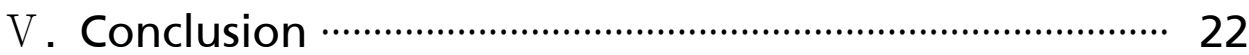

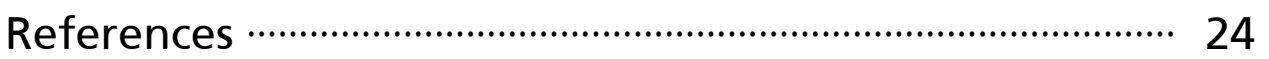

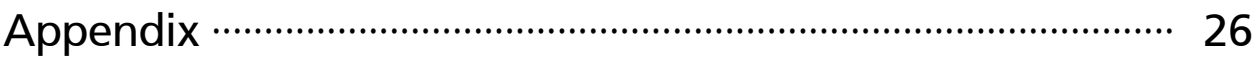




\section{Using Cheap Talk to Polarize or Unify a Group of Decision Makers}

We develop a model of strategic information transmission from an outside expert with informational superiority to a group of people who make a decision by voting on a proposal. An outside expert who observes the qualities of a proposal sends a cheap talk message to decision makers with limited information. A simple cheap talk strategy of the expert can be surprisingly effective in persuading decision makers by polarizing or unifying their opinions. When there is a significant informational gap, decision makers vote in the expert's interest by focusing only on the expert's message, even though they know she has her own bias.

Keywords: Cheap Talk, Voting, Polarization

JEL Classification Numbers: D71, D72, D78, D82, D83 


\section{Introduction}

In many economic situations, a group makes a collective decision, which determines the payoffs for all members. Moreover, decision makers may have some, but not all, of the necessary information regarding the proposal at hand. The unavailability of complete information may complicate reasonable decision making. It is common for a collective decision making body to hear advice from an outside expert who is potentially better informed about the proposal. For example, a policy-lobbying group, which has more precise information on the proposal, may give advice to a group of legislators. This well-informed agent, the expert, does not necessarily have the same preferences or incentives for specific outcomes as the deciding body. Hence the advice given must be interpreted strategically.

In this paper, we explore the information transmission from an outside expert (female) with informational superiority to a group of decision makers (male) with heterogeneous interests and private information. As far as we know, this paper is the first to examine a cheap talk model with collective decision makers who have heterogeneous preferences and private information. Cheap talk is communication between agents which does not have any direct payoff implication (Crawford and Sobel, 1982; Crawford, 1998). So, the communication is costless and non-binding for any agent, and unverifiable by a third party (Farrell, 1987). We show that a simple cheap talk strategy of an expert with informational superiority can be surprisingly effective in persuading the collective decision makers by polarizing (or unifying) their opinions and voting decisions.

More specifically, an outside expert who observes the qualities of a proposal in a two dimensional state space sends a public cheap talk message to a group of decision makers with limited information. This model is inspired by the voting example from Chakraborty and Harbaugh (2010). While their example divides uninformed voters into two groups, within which the voters have identical preferences, we introduce a group of heterogeneous decision makers with private information. Consider the 
following example. There are legislators who vote on a pipeline bill. They may ask two questions: how is the project good for the environment, and how many jobs will it create? Each legislator may put different weights on these two aspects; one may only care about either the environment or the creation of jobs, and another may care about both aspects equally. On the other side, there is an outside lobbying firm which give advice to the legislators by sending a public message. The firm knows exactly how the project will turn out, but each legislator only has partial information on it, which implies if the project is good for himself. Since the information of an individual legislator is not perfectly accurate, his voting decision may depend not only on the private information but also on the information transmitted from the lobbying firm's public message. We consider two different models based on the type of the expert; one with a highly biased expert who always wants a proposal to be defeated (e.g. a radical interest group), the other with a surplus maximizing expert who tries to maximize the total surplus of the group of decision makers (e.g. a bipartisan policy group). In each model, we demonstrate "how the expert polarizes or unifies the decision makers," in two respects. We first show that an outside expert's cheap talk message polarizes or unifies the "opinions" of the decision makers. Then, we move on to the "voting decisions" and explain how the decision makers cast votes collectively in the expert's interest without considering their private information.1)

In a cheap talk equilibrium, the highly biased expert polarizes decision makers' opinions by sending a message which asserts that the proposal is stronger in one dimension than in the other. Given the expert's message, called the "comparative cheap talk," a decision maker who cares more about the former dimension may be more favorable to the proposal, but a decision maker who cares more about the latter dimension may be less favorable.2) In

1) Since we assume a collective decision making procedure, so the sincere voting based on a voter's belief may not be an equilibrium strategy, the polarized or unified opinions may not necessarily result in the polarized or unified voting decisions. We demonstrate when and how the polarized and unified opinions lead such voting decisions.

2) Chakraborty and Harbaugh (2010) show that, mainly in a model with a single decision maker, a comparative message could be credible even when an expert is highly biased with state-independent preferences. 
other words, among the heterogeneous voting bodies, the highly biased expert strategically brings one group of decision makers over to her side, while giving up the support of the other group. In the pipeline example, the lobbying firm which always wants a bill to be defeated reveals a simple truth about the quality of the pipeline project by saying, "the project is better for jobs than it is for the environment" (or vice versa). This message polarizes the legislators into groups with opposing opinions; a group of legislators who care more about jobs believe the bill is good enough for them, and the other group who care more about environments would believe it is not.

These polarized opinions of the decision makers help the expert to achieve her goal by resulting in polarized voting behavior. We show that, under any super majority rule, the expert's manipulative cheap talk leads the decision makers to focus only on the expert's message and vote in her interest, even though they know the expert has her own bias. When there is a significant informational gap between the expert and decision makers, the decision makers' polarized perspectives cannot be significantly changed by their private information. As a result, the expert's manipulative cheap talk hinders decision makers from being responsive to their private information in the process of voting. This implies that the equilibrium voting outcome would be irrelevant to the decision makers' private information, so the voting procedure would fail in aggregating their private information. We further show that, even when the decision makers' private information is arbitrarily accurate, the expert's cheap talk strategy specified above is still better than any other strategies that transmit more or less information in equilibrium. The surplus maximizing expert, on the other hand, unifies decision makers' opinions by sending a message that reveals the overall (or average) quality of the proposal in a cheap talk equilibrium. For instance, a benevolent lobbying firm (or a bipartisan policy group) in the pipeline example may say "the overall benefit of the project along the two aspects, the number of jobs and the environment, would be sufficiently high." Given the message, all voters may believe that the proposal is good enough for them to support. So, the expert is capable of unifying the decision makers' 
opinions on the proposal. Similar to the previous case with the highly biased expert, the cheap talk message may also restrict the information aggregation among the decision makers and help the expert to achieve her goal.

Our main result is related to previous studies on the polarization of agents' beliefs. However, unlike the existing literature, which studies the effect of an exogenous public message on forming agents' beliefs, in our model, a public message is strategically transmitted from an outside expert. We show that the formation of decision makers' opinions in an equilibrium depends highly on the identity of the agent who sends a public message: in a cheap talk equilibrium, different types of experts induce different formations of the decision makers' opinions.

\section{Related Literature}

Even though most of the existing cheap talk literature after Crawford and Sobel (1982) considers a one-dimensional state variable, some studies examine multiple dimensions. Battaglini (2002) studies multidimensional cheap talk with multiple senders and a single decision maker and shows that there exists a full revelation equilibrium. Chakraborty and Harbaugh (2010) examine the credibility of a cheap talk from a "very biased expert" with state-independent preference. Their main result suggests that a multidimensional space of the state of nature guarantees the existence of an influential cheap talk equilibrium. Though they mainly focus on cheap talk models with a single decision maker, they also discuss, using a simple example, the possibility of the welfare loss of collective decision makers in a cheap talk equilibrium with a highly biased expert. We inspired by their basic setting, and generalize it with various types of voters and experts. While they only consider two groups of voters who have identical preference within groups along with a highly biased expert, we consider a voting body of which each individual has a unique preference as well as two different types of experts. Moreover, we allow voters to possess not all but 
some private information about the state of the world. With these features, we can explore how the optimal information transmission strategies vary with different types of experts and with information gaps of varying extent between a sender and a group of receivers. We can also investigate the effect of cheap talk on information aggregation among voters.

Our results are related to the literature on the polarization of opinion. The literature examines the polarized beliefs of people who observe the same public information, but have heterogeneous priors (Dixit and Weibull, 2007; Acemoglu et al., 2016) or different private information (Kondor, 2012; Andreoni and Mylovanov, 2012). While the literature studies the polarization of opinion among individuals who have private interests, we explore the polarization on voting decisions of collective decision makers who have heterogeneous interests and private information. In addition, unlike the exogenously given public signal in the polarization literature, we assume in our model that the public message is strategically transmitted from the expert who does not necessarily have the same preferences or incentives for outcomes as the deciding body. Our paper is also related to the literature on information aggregation. The primary question of information aggregation in voting literature is whether the private information of individual voters could be aggregated through strategic voting behavior of a voting body. (Feddersen and Pesendorfer, 1997) We show that, on the other hand, information aggregation among voters would be disturbed by manipulative information transmission of an outside expert, even though it allows each individual to make a more informed decision.

Several papers explore the possibility of the persuasion of a biased informed agent on a voting body. Caillaud and Tirole (2007) and Schnakenberg (2017) explore an expert's effort to persuade a voting body in the context of a mechanism design and a cheap talk, respectively. Both studies show that the outside expert could get her way by transmitting information to existing allies among a voting body, and leading persuasion cascades, through which the allies convince the other members. They paid more attention to the existence of equilibrium when there already exist the 
expert's allies among voters; relatively little is described regarding the expert's strategy to make allies among voters with various interests or preferences to get her own way in a voting outcome. On the other hand, our model with strategic information transmission illustrates the process of making allies among the heterogeneous voters, with two different types of experts.

Previous studies have also examined a cheap talk model in the context of voting. Austen-Smith and Feddersen (2002) and Rivas and Rodríguez-Álvarez (2013) focus on deliberation among voters in the form of a cheap talk. The main difference between these previous papers and our study is that a sender in those papers is one of the voters, while a sender in our study is an outside expert who does not have a vote but has complete information about the true state. Schnakenberg (2015) considers a cheap talk from an outside expert to uninformed voters where different voters care different aspects of a proposal. He relates expert's manipulation opportunity to voting rules, showing that there is a voter whose vote is always required to pass the proposal if and only if there is a cheap talk equilibrium in which all voters are worse off than in a babbling equilibrium. So, in his setting, the manipulative cheap talk does not work under the unanimity rule. On the contrary, in our setting, we show the existence of a manipulative cheap talk equilibrium in which all voters would be worse off than in a babbling equilibrium.

The remainder of the paper is organized as follows. The next section illustrates the basic model. In Section 3, we examine a model with the highly biased expert. We show the existence of equilibrium and compare the equilibrium behaviors under general super majority voting rules, and different degrees of the information gap. In Section 4, we introduce another type of the expert, the surplus maximizing expert, and conduct the equilibrium analysis. Section 5 concludes the paper. The Appendices present proofs and some more technical materials not presented in the main body of the paper. 


\section{Model}

There are an outside expert (female) and an odd number of decision makers (male) $i \in N=\{1,2, \ldots, n\}$ where $n \geq 3.3)$ Decision makers (DMs) vote on a given proposal under a certain voting rule. $q$-Majority Rule requires at least $q$ votes to approve a proposal. The state variable $\theta$ is uniformly distributed in the two dimensional state space $\Theta \equiv[0,1] \times[0,1]$, i.e. $\theta=\left(\theta_{1}, \theta_{2}\right) \sim U(\Theta)$. Each dimension represents a different aspect of the state of nature.

We denote by $u_{i}^{d}(v \mid \theta)$ the utility function of a DM $i$. A DM $i$ 's utility conditional on approval is characterized by the weighted average of the state of nature. Conditional on rejection, on the other hand, a DM $i$ 's utility is normalized to zero.

$$
u_{i}= \begin{cases}\gamma_{i} \theta_{1}+\left(1-\gamma_{i}\right) \theta_{2}-\frac{1}{2} & \text { if approved, } \\ 0 & \text { if rejected. }\end{cases}
$$

The parameter $\gamma_{i}$ which is assumed to be commonly known, captures the intensity of DM $i$ 's personal interest (or concern) on the aspect 1. That is, $\gamma_{i}=1$ means DM $i$ only cares about the aspect 1 (the first dimension), and $\gamma_{i}=0$ means DM $i$ only cares about the aspect 2 (the second dimension). We order the DMs, so if $i>j$, then $\gamma_{i}<\gamma_{j}$. In the analysis, we denote by $\tilde{u}_{i}$ the DM $i$ 's gross utility when the proposal has been approved given $\theta$, $\tilde{u}_{i} \equiv \gamma_{i} \theta_{1}+\left(1-\gamma_{i}\right) \theta_{2}-\frac{1}{2}$.

An expert privately observes the state of nature, $\theta \in \Theta$. Decision makers do not directly observe $\theta$, but receive private signals, $s_{i} \in S=\{h, l\}$ which contain partial information about $\theta$. To economize on notation, we define the region that $\mathrm{DM} i$ gets positive payoff with approval

$$
\begin{aligned}
D_{i}^{h} \equiv & \left\{\theta \in \Theta \mid \gamma_{i} \theta_{1}+\left(1-\gamma_{i}\right) \theta_{2}-\frac{1}{2}>0\right\} \text { and } D_{i}^{l} \equiv \Theta \backslash D_{i}^{h} . \text { For any } \theta \in D_{i}^{h}, \\
& P\left(s_{i}=h \mid \theta\right)=p \text { and } P\left(s_{i}=l \mid \theta\right)=1-p,
\end{aligned}
$$

3) We use the pronoun "she" for the expert and "he" for the decision makers. To economize the notion, unless otherwise stated, the term "expert" in our analysis stands for "outside expert." 
where $p \in(1 / 2,1)$. Similarly, for any $\theta \in D_{i}^{l}, \quad P\left(s_{i}=l \mid \theta\right)=p$ and $P\left(s_{i}=h \mid \theta\right)=1-p$. The value $p$, which is commonly known, represents the accuracy of DM's private information. By Bayes' rule, for a given private signal $s_{i}$, we get $P\left(\theta \in D_{i}^{h} \mid s_{i}=h\right)=p$ and $P\left(\theta \in D_{i}^{l} \mid s_{i}=h\right)=1-p$. Similarly, $P\left(\theta \in D_{i}^{l} \mid s_{i}=l\right)=p$ and $P\left(\theta \in D_{i}^{h} \mid s_{i}=l\right)=1-p$. A strategy for the expert is a function from the state space $\Theta$ to the message space $\left.M, m: \Theta \rightarrow M .{ }^{4}\right)$ A strategy for DM $i$ is a function $v_{i}: M \times S_{i} \rightarrow\{0,1\}$ that associates the expert's message and his private signal to a voting decision. For given $\widehat{m} \in M$ and $s_{i} \in S$, DM $i$ votes for the proposal $v_{i}\left(\widehat{m}, s_{i}\right)=0$ or votes against the proposal $v_{i}\left(\widehat{m}, s_{i}\right)=1$.

The game proceeds as follows:

1. Nature draws the sate $\theta \sim U(\Theta)$.

2. The expert privately observes $\theta$.

3. The expert sends a message $m(\theta) \in M$ to the group of decision makers.

4. A decision maker receives a private signal $s_{i} \in S_{i}=\{h, l\}$.

5. Each decision maker votes on the proposal, $v_{i}: M \times S_{i} \rightarrow\{0,1\}$.

6. Under $q$-majority rule, the proposal is approved only when at least $q$ decision makers vote for the proposal. Agents receive payoffs.

The solution concept employed in this paper is the perfect Bayesian equilibrium. In a perfect Bayesian equilibrium, DMs interpret any message from the expert in the same way that the expert intends them to interpret the message. So, any perfect Bayesian equilibrium can be represented by a perfect Bayesian equilibrium where the expert partitions the state space and tells DMs only which partition element the state $\theta$ belongs to.5) In the equilibrium analysis, therefore, we can simply focus on a partition type message. From now on, we write $m(\Theta) \equiv\left\{M^{k}\right\}$ and let $\widehat{M}$ denote the set of partition cheap talk strategies. To economize the notion, we denote $\left.v_{i}^{k}(h, l):=v_{i}\left(M^{k}, h\right), v_{i}\left(M^{k}, l\right)\right)$

4) In a cheap talk model, the message space $M$ can be any (Borel) set of which the cardinality exceeds that of the state space.

5) See Crawford and Sobel (1982). 
and $v^{k}=\left(v_{i}^{k}\right)_{i=1}^{n}$. We consider two different models based on the expert's interest. In the first model, the expert always prefers a rejection. We call her a "highly biased expert."

Definition 1 (Highly biased expert)

A highly biased expert is an expert whose objective is to get rejection regardless of the state of nature. The utility function of the highly biased expert is $u^{\theta}(v \mid \theta)=1-I\left\{\sum_{i}^{n} v_{i} \geq q\right\} \equiv u^{\theta}(v)$.

As in the pure persuasion game, the highly biased expert's preference is state independent (Chakraborty and Harbaugh, 2010).

In the second model, the "surplus maximizing expert" tries to maximize the total surplus of the decision makers.

Definition 2 (Surplus maximizing expert)

A surplus maximizing expert is an expert whose objective is to maximize the sum of all decision makers' utility. The utility function of the surplus maximizing expert is

$$
\begin{aligned}
u^{\theta}(v \mid \theta) & =\sum_{i=1}^{n} u^{i} \\
& = \begin{cases}\theta_{1} \sum_{i=1}^{n} \gamma_{i}+\theta_{2} \sum_{i=1}^{n}\left(1-\gamma_{i}\right)-\frac{n}{2} & \text { if approved, } \\
0 & \text { if rejected. }\end{cases}
\end{aligned}
$$

\section{Example}

We illustrate the basic ideas of this paper with the following pipeline example. There are three legislators who vote collectively on a pipeline construction bill. The voting rule is assumed to be a unanimity rule.

Figure 1 depicts the preferences of legislators. The vertical axis represents how good the project would be for the environment, and the horizontal axis represents how many jobs the project would create. The first figure from the left is for Legislator 1 with $\gamma_{1}=1$ who only cares about the number of jobs, the middle one is for Legislator 3 with $\gamma_{3}=0$ who only cares about the 
environment, and the one on the right is for Legislator 2 with $\gamma_{2}=\frac{1}{2}$ who cares about both aspects equally. The dot-dashed lines on the figures represent the cutoffs of legislators' preferences over the state of nature: if the project lies on the right hand side of the line (or over the line), then it is favorable to the legislator, and vice versa. Legislator $i$ observes a private signal $s_{i}$, which implies if the bill is good enough for himself or not. The accuracy of the private signals are simply assumed to be $p=\frac{2}{3}$ in this example.

Figure 1: Pipeline Example
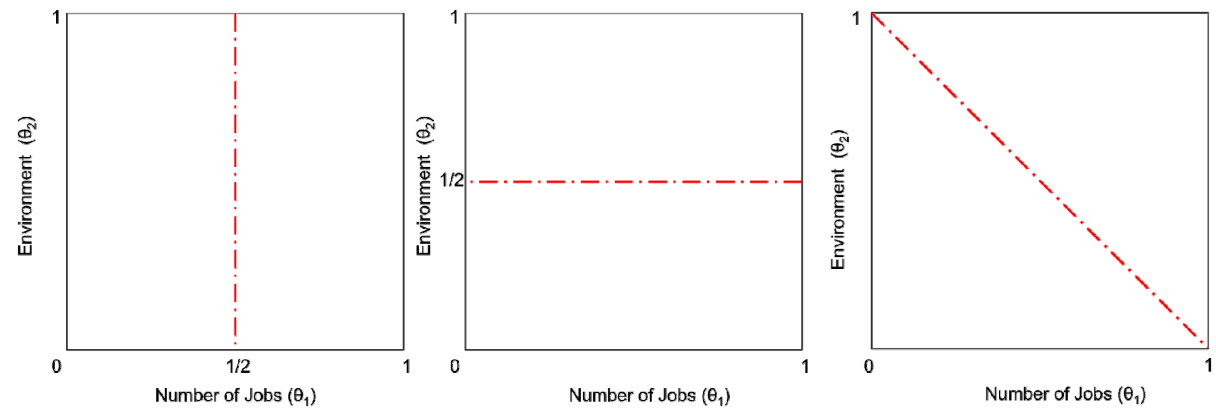

On the other side, there is an outside lobbying firm, which directly observes the quality of the project $\theta \in \Theta$. The firm gives advice to the legislators by sending a public message $m(\theta)$. Let's first consider a highly biased lobbying firm which always wants the bill to be defeated. We argue that the firm's optimal strategy is the comparative cheap talk strategy, which is formally defined as follows.

Definition 3 (Comparative Cheap Talk)

$$
m^{*}(\theta)= \begin{cases}M^{+} & \theta \in M^{+}, \\ M^{-} & \theta \in M^{-},\end{cases}
$$

where $M^{+}=\left\{\theta \in \Theta \mid \theta_{1}<\theta_{2}\right\}$ and $M^{-}=\left\{\theta \in \Theta \mid \theta_{1} \geq \theta_{2}\right\}$. 
Figure 2 depicts the two-element partition used in the comparative cheap talk strategy. A message in this comparative cheap talk indicates that the proposal is stronger in one dimension than in the other. For example, by choosing the message $M^{-}$, the lobbying firm reveals a simple truth about the quality of the pipeline project by saying, "the project is better for jobs than it is for the environment." Given this message, Legislator 3 who only cares about the environment would be less favorable toward the bill, while Legislator 1 who only cares about the number of jobs would be more favorable. That is, the comparative cheap talk polarizes the legislators' opinions.

Figure 2: Comparative Cheap Talk

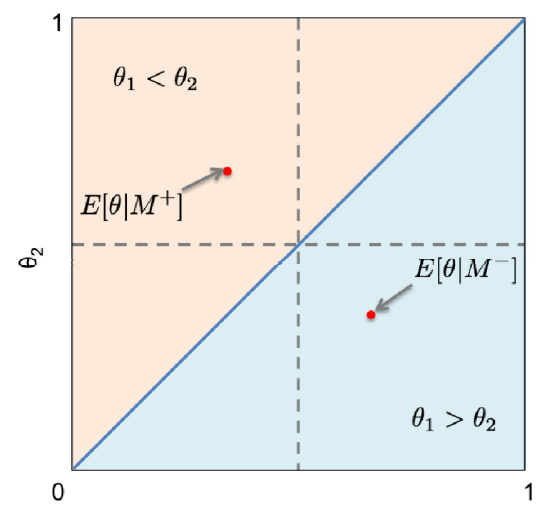

$\theta_{1}$
Figure 3: Overall Cheap Talk

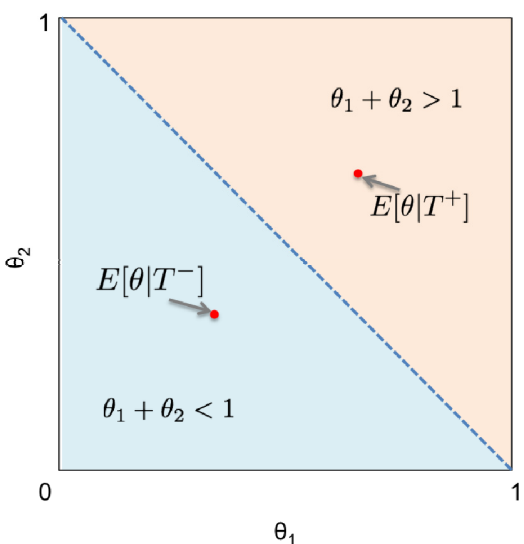

These polarized beliefs sustain even after each legislator observes his private signal. As a result, in an equilibrium, at least one legislator votes against the proposal, so the bill is always rejected: $v_{1}\left(M^{-}\right)=v_{2}\left(M^{-}\right)=(1,1)$ and $v_{n}\left(M^{-}\right)=(0,0)$. In this equilibrium, even though the legislators know the expert has her own bias, they ignore their private signals and vote collectively in the expert's interest. It means that, even when the project is really good for everyone or all private signals say the bill is good for the legislators, the project will always be rejected. 
Now consider the surplus maximizing expert. We argue that the overall cheap talk strategy defined as follows is the best cheap talk strategy for the surplus maximizing expert.

\section{Definition 4 (Overall Cheap Talk)}

$$
t^{*}(\theta)= \begin{cases}T^{+} & \theta \in T^{+}, \\ T^{-} & \theta \in T^{-}\end{cases}
$$

where $T^{+}=\left\{\theta \in \Theta \mid \theta_{1}+\theta_{2}>1\right\}$ and $T^{-}=\left\{\theta \in \Theta \mid \theta_{1}+\theta_{2} \leq 1\right\}$.

This cheap talk strategy reveals the overall qualities of the state of nature by saying that the proposal is good along the both aspects or not. By sending this message, the expert is capable of unifying the decision makers' opinions. Figure 3 graphs the overall cheap talk strategy. The message $T^{+}$indicates that the proposal's overall quality is good along both dimensions, and $T^{-}$says it is bad. Given these messages, as in the previous case with the biased expert, the legislators ignore their private information and vote in the expert's favor. For example, given $T^{+}$, all legislators believe the bill is good enough for each of them, even when their private signals say it is bad. So, all of them vote for the proposal, $v_{i}\left(T^{+}, s_{i}\right)=1$ for all $i$, and the bill is always accepted. Similarly, given $T^{-}$, the bill is always rejected.

From this example, we can conclude that the expert's simple cheap talk strategy could be surprisingly effective in persuading voters. In addition, when there is a sufficient informational gap between the expert and the decision makers, the voters ignore their private information and vote according to the expert's suggestion. One may wonder if this persuading power of expert depend on the voting rule as well as the informational gap. In the general analysis below, we discuss how robust the result presented with this pipeline example is to voting rules and/or the level of informational gap. 


\section{General Model and Equilibrium}

In our generalized model, for analytical convenience, we assume that the

decision makers are symmetric around $\frac{n+1}{2}$-th decision maker: $\gamma_{\frac{n+1}{2}}=\frac{1}{2}$, and $\gamma_{n-j+1}=1-\gamma_{j}$ for any $j$ such that $\frac{n+1}{2}>j>1$. This assumption could be relaxed without altering the basic implication of the analysis.

In a simultaneous voting game, there always exists a trivial equilibrium in which no voter (or decision maker) is pivotal. In such a trivial equilibrium, an equilibrium outcome would not be affected by neither the information that may be transmitted from an expert nor the private information that a decision maker may posses, since no unilateral deviation caused by a change in an agent's belief would affect the voting outcome. For example, under unanimity, an equilibrium where all DMs always vote against the proposal would be a trivial equilibrium in which no information matters. Therefore, in order to sharpen predictions and rule out inappropriate equilibrium, we would like to focus mainly on "non-trivial equilibrium" in which there exists at least one decision maker, who is pivotal with a positive probability. To economize the notion, unless otherwise stated, the term "equilibrium" in our analysis stands for "non-trivial equilibrium," which is formally defined as follows.

\section{Definition 5 (Non-trivial equilibrium)}

An equilibrium is non-trivial if, in any information set on the equilibrium path, there exists a decision maker with a positive probability of being pivotal. More precisely, in a non-trivial equilibrium, for any equilibrium message $M^{k^{*}} \in m(\Theta)$ and the corresponding equilibrium voting strategy profile $v^{k^{*}}$, there exists a decision maker, DM $i$, such that

$$
\begin{aligned}
& \sum_{j \neq i} I\left\{v_{j}^{*}\left(M^{k^{*}}, h\right)+v_{j}^{*}\left(M^{k^{*}}, l\right)>0\right\} \geq q-1 \text { and } \\
& \sum_{j \neq i} I\left\{v_{j}^{*}\left(M^{k^{*}}, h\right)+v_{j}^{*}\left(M^{k^{*}}, l\right)=2\right\}<q .
\end{aligned}
$$


In our voting game, on equilibrium paths, a voter's interim expected utility from the approved proposal cannot be lower with a high private signal than with a low private signal. So, it would be only reasonable to focus on an equilibrium where a voter votes for the proposal with a high signal whenever he votes for the proposal with a low signal. Therefore, we reduce our attention to an equilibrium in which each decision maker's voting strategy on an equilibrium path has a property such that, for a given $M^{k} \in m(\Theta)$, $\left.v_{i}\left(M^{k}, h\right) \geq v_{i}\left(M^{k}, l\right) .6\right)$

Furthermore, we occasionally restrict our attention to an equilibrium including a voting profile with a specific property. In an equilibrium with a monotonic voting profile, given an expert equilibrium message $M^{k} \in m(\Theta)$, a $\mathrm{DM}$ votes for the proposal whenever a tougher DM votes for the proposal.

\section{Definition 6 (Monotonic Voting Profile)}

A voting strategy profile $v=\left(v_{i}\right)_{i=1}^{n}$ is monotonic if, given equilibrium message $M^{k} \in m(\Theta), E\left[\widetilde{u_{i}} \mid M^{k}\right] \geq E\left[\widetilde{u_{j}} \mid M^{k}\right] \Rightarrow v_{i}^{k} \geq v_{j}^{k}$, for any $i$ and $j$. We let $\widehat{V}$ denote the set of monotonic voting profiles.

In analysis, we often prove this property holds in an equilibrium, but at times, we simply focus on an equilibrium which satisfies this property for technical convenience.

\section{Highly Biased Expert}

In this section, we consider a highly biased expert who always prefers the rejection and show the comparative cheap talk (See Definition 3) is the best strategy for the expert. In analysis, we show that there exists a non-trivial equilibrium with the comparative cheap strategy specified above, and argue that it is the best strategy the expert can take. We first discuss the existence of a rejection equilibrium in which the proposal is always rejected given the comparative cheap talk strategy under $q$-majority rule.

6) Note that, given $M^{k}$ on the equilibrium path, a pivotal DM's equilibrium strategy should always satisfies this property. Proposition 6 in Appendix proves this. 
Proposition 1 Consider $q$-majority rule where $\frac{n+1}{2}<q \leq n$. Define $\bar{p}(q)=1-\frac{1}{8 \gamma_{n-(q-1)}^{2}-4 \gamma_{n-(q-1)}+2}$.

1. If $p \leq \bar{p}(q)$, there exists a rejection equilibrium with the comparative cheap talk $m^{*}(\theta)$ which is optimal for the highly biased expert.

2. Specifically, if $p \leq \bar{p}(q)$, there exists an equilibrium with a cheap talk strategy $m^{*}(\theta)$ and a voting strategy $\left\{v^{+}, v^{-}\right\}$such that

(a) for $M^{+}, \tilde{v}_{i \leq n-(q-1)}^{+}=(0,0)$ and $\tilde{v}_{i>n-(q-1)}^{+}=(1,1)$ and

(b) for $M^{-}, \tilde{v}_{i \geq q)}^{-}=(0,0)$ and $\tilde{v}_{i<q}^{-}=(1,1)$.

3. If $p>\bar{p}(q)$, there is no rejection equilibrium with any cheap talk strategy $m \in \widehat{M}$.

Proposition 1 suggests that, when the accuracy of the decision makers' private signals is sufficiently low $p \leq \bar{p}(q)$, there always exists an equilibrium that guarantees the rejection of the proposal. In the equilibrium, the expert's comparative cheap talk polarizes the decision makers' opinions and here is how. A cheap talk message $M^{+}\left(M^{-}\right)$ranks the DMs in descending (increasing) order of $\gamma_{i}$, and makes the highest-ranked DM the least favorable toward the proposal, the second-highest ranked DM the second-least favorable, and so on. For example, by sending the message $M^{+}=\left\{\theta \mid \theta_{2}>\theta_{1}\right\}$, DM 1 with $\gamma_{i}=1$, who only cares about $\theta_{1}$, would be least favorable toward the proposal, while DM $n$ with $\gamma_{n}=0$ would be most favorable. As a result, given the cheap talk message, about a half of DMs becomes favorable toward the proposal, $E\left(\tilde{u}_{i} \mid M^{+}\right)>0$ for $i>\frac{n+1}{2}$, and the other half becomes unfavorable, $E\left(\tilde{u}_{i} \mid M^{+}\right)<0$ for $i<\frac{n+1}{2}$.

By polarizing DMs' opinions, the expert can guarantee enough 'nay' votes for the proposal to be defeated. When the DMs' private information is sufficiently inaccurate, DMs' opinions formed by the expert message may not easily be overturned. The least favorable DMs' opinions may sill be negative 
on the proposal after observing their private signals, $E\left(\tilde{u}_{i} \mid M^{+}, s_{i}\right)<0$. In Proposition 1, we show that enough number of DMs always vote against the proposal regardless of their private signals. It means that DMs collectively vote in the expert's interest, even when all of them are received high private signals. Consequentially, the voting outcome, which is the rejection of the proposal in this case, does not depend on the DMs' private information.

The characterized equilibrium in Proposition 1 is one typical example of the rejection equilibrium with polarized opinions and voting decisions. We observe two groups of DMs; one who always vote for the proposal regardless of their private signals and the other who always vote against it. No one is paying attention to their private information, and at the same time, the cheap talk message as a public information polarizes the DMs' voting behavior. Therefore, when the DMs' private information is sufficiently inaccurate, the voters ignore their private information and collectively vote in the expert's interest.7) It means that, even when the quality of the proposal is really good for everyone or when all private signals say the proposal is good for the DMs, the expert's manipulative cheap talk always makes the proposal rejected. Under this manipulation, the voting procedure fails to aggregate the private information of the voting body.

To sum up, the expert's comparative cheap talk message polarizes the DMs in two respects: beliefs and voting decisions. The expert's cheap talk (1) polarizes the DMs into two groups based on their beliefs and (2) makes the DMs vote collectively in the expert's interest without paying attention to their private information.

Note that $8 \gamma_{n-(q-1)}^{2}-4 \gamma_{n-(q-1)}+2$ is increasing in $\gamma_{n-(q-1)}$ and $\gamma_{n-(q-1)}$ is increasing in $q$. So, $\frac{\partial \bar{p}(q)}{\partial q}>0$. Proposition 1 demonstrates that the

7) With two intra-identical groups of voters, Chakraborty and Harbaugh (2010) argue that the expert would be better off by "attracting one group of voters at the expense of alienating the other." They call this a divisive effect of comparative cheap talk. So basically, they show that, in order to get her own way, the expert exploits the fact that voters has already been polarized in two groups. With more generalized model with $n$ voters with diverse interests, we further show that the expert's cheap talk polarizes the voters into two groups with opposing opinions on the proposal, as well as cajoles one group into voting against the proposal. 
manipulating power of getting rejection is stronger under a tougher voting rule with higher $q$.

Then, what if $p>\bar{p}(q)$. Since there are too many pivotal events to consider and the existence of a cheap talk equilibrium may highly depends on the specific distribution of DMs' preference parameters $\gamma$ 's, it is almost impossible to characterize a cheap talk equilibrium for all possible values of $p \in(0,1)$. However, we may infer the general result from the results with unanimity and simple majority.

For unanimity, even though there is no equilibrium in which the rejection is always guaranteed, the comparative cheap talk is still the best strategy for the highly biased expert. The following proposition demonstrates a cheap talk equilibrium when $p>\bar{p}(q)$.

Proposition 2 Consider the unanimity rule, $q=n$.

1. If $p>\bar{p}(q)$, there is a non-trivial equilibrium with the comparative cheap talk $m^{*}(\theta)$

2. Specifically, if $p>\bar{p}(q)$, there exists an equilibrium with a cheap talk strategy $m^{*}(\theta)$ and a voting strategy $\left\{v^{+}, v^{-}\right\}$such that

(a) for $M^{+}, \tilde{v}_{i \leq n-q+2}^{+}=(1,0)$ and $\tilde{v}_{i>n-q+2}^{+}=(1,1)$ and

(b) for $M^{-}, \tilde{v}_{i \geq q-1}^{-}=(1,0)$ and $\tilde{v}_{i<q-1}^{+}=(1,1)$.

3. Moreover, no cheap talk strategy $m \in \widehat{M}$ along with a monotonic voting profile $v \in \hat{V}$ gives the expert a higher equilibrium payoff than the comparative cheap talk strategy $m^{*}(\theta)$ along with the voting strategy $\left\{v^{+}, v^{-}\right\}$characterized above.

As stated in Proposition 1, no rejection equilibrium exists when $p>\bar{p}(q=n)$. So, the optimality of the comparative cheap talk strategy $m^{*}(\theta)$ maybe now be in question. But we still argue that the comparative cheap talk strategy is better for the expert than any other cheap talk strategy $m \in \widehat{M}$ (the item 3 of Proposition 2).

Similar to the case with lower value of $p$, when $p>\bar{p}(q=n)$, the expert's comparative cheap talk orders the DMs in $\gamma_{i}$ and polarizes their beliefs. In a 
strategic voting game, these ordered and polarized DMs delegate the group decision to toughest DMs given an expert's message: For example, given $M^{+}$, DM 1 and 2 vote according to their individual private signals and all others delegate their decisions to the two toughest ones by voting for the proposal. So, compare to a babbling equilibrium, which we characterize in Appendix 3, the proposal is more likely to be rejected in the equilibrium characterized in Proposition 2.

Then, why any other cheap talk strategy $m \in \widehat{M}$ does not make the expert better off? We here provide some intuitive explanations. (See Appendix 1.1.1 for the formal argument.) Suppose an arbitrary cheap talk message $M \in m(\Theta)$ for an equilibrium cheap talk strategy $m$. Given the message, it is either $E\left(\theta_{1} \mid M\right)<E\left(\theta_{2} \mid M\right)$ or $E\left(\theta_{1} \mid M\right) \geq E\left(\theta_{2} \mid M\right)$. The former makes DM 1 the toughest as in $M^{+}$, and the latter makes DM $n$ the toughest as in $M^{-}$. It means that the message ranks DMs in decreasing or increasing orders as the comparative cheap talk does. Note that, given any messages which induces the same ordering, DMs's delegation behavior and voting strategies should be similar: The tougher a DM is, the more conservative voting strategy he takes. ${ }^{8}$ ) So, with any arbitrary equilibrium cheap talk strategy $m$, there cannot be any further advantage from the schemed ordering for the expert. Moreover, the expert could even be worse off if a cheap talk message provides too much information to the DMs. That is, if a cheap talk allows DMs more informed decisions, then it may weaken the expert's manipulation power. To sum up, by taking any equilibrium cheap talk strategy $m \in \widehat{M}$ other than $m^{*}$, the expert will not gain any further advantage from schemed ordering, and may even lose some manipulating power because of the excessive information transmission.

We now consider the simple majority voting rule, $q=\frac{n+1}{2}$. Note that $\bar{p}\left(q=\frac{n+1}{2}\right)=\frac{1}{2}$. That is, Proposition 1 already shows that there is no

8) Also note that, in a partition equilibrium with $m$, there cannot be a big difference between the expert's expected payoff from one message and another. For example, if one message guarantees the rejection and another doesn't, the former message cannot be credible, because the expert would not have any incentive to send the latter message. 
rejection equilibrium under majority for any value of $p>\frac{1}{2}$. In other words, the highly biased expert loses the manipulating power of getting rejection under majority. The following proposition characterizes a non-trivial cheap talk equilibrium under majority.

Proposition 3 Consider the simple majority rule, $q=\frac{n+1}{2}$.

For any $n$ and $p$,

1. there is an equilibrium with the comparative cheap talk $m^{*}(\theta)$ which is optimal for the highly biased expert.

2. Specifically, there exists an equilibrium with a cheap talk strategy $m^{*}(\theta)$ and a voting strategy $\left\{v^{+}, v^{-}\right\}$such that

(a) for $M^{+}, v_{i>q}^{+}=(1,1), v_{i<q}^{+}=(0,0)$ and $v_{i=q}^{+}=(1,0)$.

(b) for $M^{-}, v_{i>q}^{+}=(0,0), v_{i<q}^{+}=(1,1)$ and $v_{i=q}^{+}=(1,0)$.

3. Moreover, no cheap talk strategy $m \in \widehat{M}$ along with a monotonic voting profile $v \in \hat{V}$ gives the expert a higher equilibrium payoff than the comparative cheap talk strategy $m^{*}(\theta)$.

Though the cheap talk message may lose the power of getting rejection in expectation, however, its functions of polarizing DMs' beliefs and preventing voting procedure from aggregating DMs' information have still performed well. In a babbling equilibrium under majority, all DMs information would be aggregated in the voting outcome since all DMs' voting strategies depend on their own private signals. (See Appendix 3) On the other hand, in the cheap talk equilibrium characterized in Proposition 1, only one DM's voting strategy-the median DM's voting strategy $v_{q}$-depends on his private signal. All DM other than the median DM $q$ are polarized into two groups: Those who always vote for the proposal and the other who always vote against it. Their private information would not be aggregated in the voting outcome. 
We can also easily show that, as in the case under unanimity, the comparative cheap talk strategy is better than any other strategy with a monotonic voting profile $m \in \widehat{M}$. That is the expert's ex-ante expected payoff is not lower in the cheap talk equilibrium characterized above than in any other equilibrium with $\left.m \in \widehat{M}{ }^{9}{ }^{9}\right)$ To sum up, under majority, though the manipulating power of getting rejection is weakened, the comparative cheap talk strategy still has a significant manipulating power of polarizing DMs' beliefs and preventing them from aggregating their private information.

\section{Surplus Maximizing Expert}

In this section, we consider a surplus maximizing expert instead of a biased expert. For the technical convenience, suppose $q$ as well as $n$ are odd numbers and define $\kappa(q)-\frac{n-q}{2}+1$ and $\hat{p}(q)=\frac{1}{2}+\frac{\gamma_{\kappa(q)}}{4 \gamma_{\kappa(q)}^{2}-2 \gamma_{\kappa(q)}+1}$.

Proposition 4 Consider $q$-majority rule.

1. For any value of $p \leq \hat{p}(q)$, there exists a non-trivial equilibrium which maximizes the total surplus of the decision makers.

2. For any value of $p \leq \hat{p}(n)$, there exists a sincere voting equilibrium in which the overall cheap talk unifies the DMs; all DMs vote for the proposal given the message $T^{+}$and vote against it given $T^{-}$.

Proposition 4 shows that, when there is a sufficient informational gap between the expert and DMs, the expert's overall cheap talk now unifies the DMs' beliefs and voting behavior. In a cheap talk equilibrium, given the overall cheap talk message $T^{+}$(or $T^{-}$), all DMs believe the proposal is good (or bad) for them. Because any negative private signal $s_{i}=l$ cannot overturn the DM $i$ 's belief on the proposal given the expert's cheap talk message $T^{+}$(or $T^{-}$), a DM votes only according to the expert's suggestions. Therefore, DMs' votes in a

9) See Proposition 3 in Appendix. The ex-ante expected payoff of the expert in this cheap talk equilibrium is the same as in the babbling equilibrium. 
cheap talk equilibrium are unified.

It is easy to show that $\hat{p}(q)$ is increasing in $q$. So, the item 1 in Proposition 4 demonstrates that, there exists a surplus maximizing equilibrium with an even higher value of $p$ under a voting rule with a higher value of $q$. Unlike the highly biased expert, the surplus maximizing expert's manipulating power is stronger under majority than under unanimity. Moreover, the item 2 in Proposition 4 shows that the expert's power of unifying DMs opinions is not weaker under a tougher voting rule with a higher $q$.

The different features in the persuading power can be explained by the difference in the intended opinion-forming strategies between the highly biased expert and the surplus maximizing expert. The highly biased expert polarizes DMs opinions. Among the group of DMs with polarized opinions, a DM is more likely to be pivotal under majority than under unanimity. Therefore, a DM may be more sensitive and responsive to his private information under majority. The surplus maximizing expert, on the other hand, unifies DMs opinions. Among the group of DMs with unified opinions, a DM is less likely to be pivotal under majority than under unanimity. So, a DM may be less responsive to his private information under majority. Accordingly, it is easier for the surplus maximizing expert to get her way under majority.

When $p>\hat{p}(q)$, the overall cheap talk may not induce the surplus maximizing result all the time. As in the model with a highly biased expert, however, we can still show that, if DMs' voting profile is monotonic in the expected utility given the cheap talk message in equilibrium, the overall cheap talk is better than any other cheap talk strategy $t \in \widehat{M}$ under unanimity.

Proposition 5 Consider the unanimity rule, $q=n$. For any value of $p>\hat{p}(n)$,

1. there exists a non-trivial equilibrium with the overall cheap talk $t^{*}(\theta)$.

2. Moreover, no cheap talk strategy $t \in \widehat{M}$ along with a symmetric and monotonic voting profile $v \in \hat{V}$ gives the expert a higher equilibrium payoff than the comparative cheap talk strategy $t^{*}(\theta)$. 


\section{Conclusion}

This paper develops a model of strategic information transmission from an outside expert with informational superiority to a group of people who make a collective decision by voting on a proposal. In a multidimensional cheap talk model with collective decision makers, we show that a simple cheap talk strategy of an outside expert with informational superiority can be surprisingly effective in persuading the collective decision makers by polarizing (or unifying) their beliefs and voting decisions. First, an expert's cheap talk message polarizes or unifies the beliefs of decision makers who have heterogeneous preferences. Second, these polarized (or unified) beliefs of decision makers result in the voting outcome that the expert prefers. In other words, the expert's cheap talk makes the decision makers vote collectively in the expert's interest without paying attention to their private information.

More specifically, we show that, in a cheap talk equilibrium, the highly biased expert polarizes decision makers' opinions by sending a message which says the proposal is stronger in one dimension than in the other, whereas the surplus maximizing expert unifies them by sending a message which reveals the overall qualities. When there is a significant informational gap between an expert and decision makers, decision makers vote according to the expert's interest by focusing only on the expert's message, even though they know the expert has her own bias. This implies that the equilibrium voting outcome would be irrelevant to the decision makers' private information, so the voting procedure would fail in aggregating their private information.

The findings of this paper provide important economic implications for collective decision making. Even though, as shown in the previous literature (de Condorcet, 1785; Klevorick et al., 1984), collective decision making has its own merit such that it can aggregate various opinions or information among multiple individuals, it can be surprisingly vulnerable to a strategic persuasion by a biased expert who has informational superiority over the decision making body. In particular, an outside expert who always wants to 
get a rejection of a proposal can easily polarize the decision makers' opinions and make them fight with each other to get her own way, when she has a significant informational superiority over the decision makers. Therefore, to nip the evil in the bud, it is very important to appoint a committee with professional expertise and intelligence regarding the decisions they are supposed to make. In this sense, a monetary policy committee or a congressional committee would be classic examples of committees consisting of professionals in certain fields: Since the professional expertise would be the first criterion in appointing such committees, a well-organized committee may not be so easily swayed by a voice of an outside adviser.

Furthermore, a committee, if they have formed, should be extremely prudent in choosing outside advisers to listen to or reports to focus on. For example, members of jury in a trial could be easily manipulated by defense attorneys who try to persuade them to acquit a defendant. So, in this case, a judge should guide jury, who hardly have professional expertise in trial law, to the right evidences to focus on. This argument can also justify professional decision makers in taking a critical view of the opinions of self-interested groups. When it comes to "modern central banks," as Blinder (2004, Chapter 3) argues, they take advice as well as information from financial markets. So, when a monetary policy committee member or a staff of a central bank considers taking such advice and/or information from an outside expert, especially from financial market participants only following their own self-interest, one should note that the expert can act like a "strategic persuader" in our model and try to manipulate the decision making procedure. In order to test the above theory, in a future work, we plan to conduct laboratory experiments. As in a general cheap talk model, there exists an essential multiplicity of equilibria in our model. In laboratory experiments, we would like to check whether subjects' behavior coincides with the equilibrium predictions. We want to check if 1) an expert uses cheap talk to persuade a group of voters, 2) the expert's cheap talk is more informative under unanimity than under majority, and 3) voting decisions are polarized (or unified) given the expert's cheap talk. 


\section{References}

Acemoglu, D., Chernozhukov, V., and Yildiz, M. (2016), "Fragility of Asymptotic Agreement under Bayesian Learning," Theoretical Economics, Vol. 11(1).

Andreoni, J. and Mylovanov, T. (2012), "Diverging Opinions," American Economic Journal: Microeconomics, Vol. 4(1), pp. 209-232.

Austen-Smith, D. and Feddersen, T. (2002), "Deliberation and Voting Rules," Discussion Papers 1359, Northwestern University, Center for Mathematical Studies in Economics and Management Science.

Battaglini, M. (2002), "Multiple Referrals and Multidimensional Cheap Talk," Econometrica, Vol. 70(4), pp. 1379-1401.

Blinder, A. S. (2004), The Quiet Revolution : Central Banking Goes Modern, Yale University Press, New Haven.

Caillaud, B. and Tirole, J. (2007), "Consensus Building: How to Persuade a Group,” American Economic Review, Vol. 97(5), pp. 1877-1900.

Chakraborty, A. and Harbaugh, R. (2010), "Persuasion by Cheap Talk," American Economic Review, Vol. 100(5), pp. 2361-2382.

Crawford, V. P. and Sobel, J. (1982), "Strategic Information Transmission," Econometrica, Vol. 50(6), pp. 1431-1451.

Crawford, V. (1998), "A Survey of Experiments on Communication via Cheap Talk," Journal of Economic Theory, Vol. 78(2), pp. 286-298.

de Condorcet, M. (1785), Essai sur l'application de l'analyse à la probabilité des décisions rendues à la pluralité des voix. De l'Imprimerie royale, Paris.

Dixit, A. K. and Weibull, J. W. (2007), "Proceedings of the National Academy of Sciences," Vol. 104(18), pp. 7351-7356, http://www.pnas.org/content/104/18/7351.full.pdfPolitical polarization.

Farrell, J. (1987), "Cheap Talk, Coordination, and Entry," The RAND Journal of Economics, Vol. 18(1) pp. 34-39. 
Feddersen, T. and Pesendorfer, W. (1997), "Voting Behavior and Information Aggregation in Elections with Private Information," Econometrica, Vol. 65(5), pp. 1029-1058.

Klevorick, A. K., Rothschild, M., and Winship, C. (1984), "Information Processing and Jury Decisionmaking," Journal of Public Economics, Vol. 23(3), pp. 245-278.

Kondor, P. (2012), "The More We Know about the Fundamental, the Less We Agree on the Price," Review of Economic Studies, Vol. 79(3), pp. 1175-1207.

Rivas, J. and Rodríguez-Álvarez, C. (2013), Deliberation, Leadership and Information Aggregation, Mimeo.

Schnakenberg, K. E. (2015), "Expert Advice to a Voting Body," Journal of Economic Theory, Vol. 160, pp. 102-113.

Schnakenberg, K. E. (2017), "Informational Lobbying and Legislative Voting," American Journal of Political Science, Vol. 61(1), pp. 129145 . 


\section{Appendix}

\section{General Model}

\subsection{Highly Biased Expert}

Lemma 1 (Monotonicity of Conditional Expectations with a Private Signal)

$$
\begin{aligned}
& \text { 1. For } M^{k} \subseteq M^{+}, \frac{\partial E\left[\tilde{u}_{i} \mid M^{k}, s_{i}^{k}\right]}{\partial \gamma_{i}}<0 \text {. For } M^{k} \subseteq M^{-}, \frac{\partial E\left[\tilde{u}_{i} \mid M^{k}, s_{i}^{k}\right]}{\partial \gamma_{i}}>0 \\
& \text { 2. For } M^{k} \subseteq M^{+}, \frac{\partial E\left[\tilde{u}_{i} \mid M^{k}, s_{i}^{n}\right]}{\partial \gamma_{i}}<0 \text {. For } M^{k} \subseteq M^{-}, \frac{\partial E\left[\tilde{u}_{i} \mid M^{k}, s_{i}^{n}\right]}{\partial \gamma_{i}}>0 \text {. }
\end{aligned}
$$

Proof of Part of lemma 1. Suppose $\gamma_{i}>\gamma_{j}$. For any $M^{k} \subseteq M^{+}$, define $M_{++}^{k}=M^{k} \cap D_{i}^{h}, \quad M_{-+}^{k}=M^{k} \cap D_{j}^{h} \cap D_{i}^{l}, \quad$ and $M_{--}^{k}=M^{k} \cap D_{j}^{l}$. And denote $\mathscr{M}^{k} \equiv\left\{M_{++}^{k}, M_{-+}^{k}, M_{--}^{k}\right\}$. We know $E\left[\tilde{u}_{i} \mid M^{k}, s_{i}^{l}\right]=\Sigma_{M \in M^{k}} \operatorname{Pr}\left(M^{\prime} \mid M^{k}, s_{i}^{l}\right) E\left[\tilde{u}_{i} \mid M^{\prime}, s_{i}^{l}\right]$. And similarly, $\quad E\left[\tilde{u}_{j} \mid M^{k}, s_{j}^{l}\right]=\sum_{M^{\prime} \in M^{k}} \operatorname{Pr}\left(\tilde{M}^{k} \mid M^{k}, s_{j}^{l}\right) E\left[\tilde{u}_{j} \mid \mathscr{M}^{k}, s_{j}^{l}\right]$. Since $E\left[\tilde{u}_{a} \mid M_{++}^{k}, s_{a}^{l}\right]=E\left[\tilde{u}_{a} \mid M_{-+}^{k}\right], E\left[\tilde{u}_{a} \mid M_{-+}^{k}, s_{a}^{l}\right]=E\left[\tilde{u}_{a} \mid M_{-+}^{k}\right], E\left[\tilde{u}_{a} \mid M_{-+}^{k}, s_{a}^{l}\right]=E\left[\tilde{u}_{a} \mid M_{-+}^{k}\right]$ and $E\left[\tilde{u}_{a} \mid M_{--}^{k}, s_{a}^{l}\right]=E\left[\tilde{u}_{a} \mid M_{--}^{k}\right]$.

We know $E\left[\tilde{u}_{i} \mid M^{k}\right]<E\left[\tilde{u}_{j} \mid M^{k}\right]$ for any $M^{k} \cap M^{+}$, so $0<E\left[\tilde{u}_{i} \mid M_{++}^{k}, s_{i}^{l}\right]<E\left[\tilde{u}_{j} \mid M_{++}^{k}, s_{j}^{l}\right]$.

Similarly, we have $E\left[\tilde{u}_{i} \mid M_{-+}^{k}, s_{i}^{l}\right]<0<E\left[\tilde{u}_{j} \mid M_{-+}^{k}, s_{j}^{l}\right]$, and $E\left[\tilde{u}_{i} \mid M_{--}^{k}, s_{i}^{l}\right]<E\left[\tilde{u}_{j} \mid M_{--,}^{k}, s_{j}^{l}\right]<0$.

For the conditional probability, we have $\operatorname{Pr}\left(M^{k}, s_{i}^{l}\right)=(1-p)\left|M_{++}^{k}\right|+p\left(\left|M_{-+}^{k}\right|+\left|M_{--}^{k}\right|\right)$

$\geq \operatorname{Pr}\left(M^{k}, s_{j}^{l}\right)=(1-p)\left(\left|M_{++}^{k}\right|+\left|M_{-+}^{k}\right|\right)+p\left|M_{--}^{k}\right|$.

So we have $\operatorname{Pr}\left(M_{++}^{k}, s_{i}^{l} \mid M^{k}, s_{i}^{l}\right)=\frac{(1-p)\left|M_{++}^{k}\right|}{\operatorname{Pr}\left(M^{k}, s_{i}^{l}\right)} \leq \operatorname{Pr}\left(M_{++}^{k}, s_{j}^{l} \mid M^{k}, s_{j}^{l}\right)=\frac{(1-p)\left|M_{++}^{k}\right|}{\operatorname{Pr}\left(M^{k}, s_{j}^{l}\right)}$, which implies

$$
\operatorname{Pr}\left(M_{++}^{k}, s_{i}^{l} \mid M^{k}, s_{i}^{l}\right) E\left[\tilde{u}_{i} \mid M_{++}^{k}, s_{i}^{l}\right]<\operatorname{Pr}\left(M_{++}^{k}, s_{j}^{l} \mid M^{k}, s_{j}^{l}\right) E\left[\tilde{u}_{j} \mid M_{++}^{k}, s_{j}^{l}\right] .
$$


Similarly, we have $\operatorname{Pr}\left(M_{--}^{k}, s_{i}^{l} \mid M^{k}, s_{i}^{l}\right)=\frac{p\left|M_{-}^{k}\right|}{\operatorname{Pr}\left(M^{k}, s_{i}^{l}\right)} \leq \operatorname{Pr}\left(M_{--}^{k}, s_{j}^{l} \mid M^{k}, s_{j}^{l}\right)=\frac{p\left|M_{-}^{k}\right|}{\operatorname{Pr}\left(M^{k}, s_{j}^{l}\right)}$, which implies

$$
\operatorname{Pr}\left(M_{--}^{k}, s_{i}^{l} \mid M^{k}, s_{i}^{l}\right) E\left[\tilde{u}_{i} \mid M_{--}^{k}, s_{i}^{l}\right]<\operatorname{Pr}\left(M_{-,}^{k}, s_{j}^{l} \mid M^{k}, s_{j}^{l}\right) E\left[\tilde{u}_{j} \mid M_{-,}^{k}, s_{j}^{l}\right] .
$$

And the following is always true for any $\operatorname{Pr}\left(M_{-+}^{k} \mid M^{k}, s_{i}^{l}\right) \geq 0$ and $\operatorname{Pr}\left(M_{-+}^{k} \mid M^{k}, s_{j}^{l}\right) \geq 0$.

$$
\operatorname{Pr}\left(M_{-+}^{k} \mid M^{k}, s_{i}^{l}\right) E\left[\tilde{u}_{i} \mid M_{-+}^{k}, s_{i}^{l}\right] \leq 0 \leq \operatorname{Pr}\left(M_{-+}^{k} \mid M^{k}, s_{j}^{l}\right) E\left[\tilde{u}_{j} \mid M_{-+}^{k}, s_{j}^{k}\right] .
$$

Therefore, from Equations (1.1), (1.3) and (1.2), we get $E\left[\tilde{u}_{i} \mid M^{k}, s_{i}^{l}\right]<E\left[\tilde{u}_{j} \mid M^{k}, s_{j}^{l}\right]$.

The proof of Part 2 is just a symmetric argument.

Lemma 2 (Rejection Equilibrium Property)

Consider a $q$-majority rule. If there is no rejection equilibrium with $\left\{M^{+}, M^{-}\right\}$, there is no rejection equilibrium with any arbitrary partition $\left\{M^{k}\right\}$.

Proof. We prove by contradiction. Let's suppose there is a rejection equilibrium with $\left(\left\{v^{k}\right\},\left\{M^{k}\right\}\right)$. For any $M^{k} \in\left\{M^{k}\right\}, \quad$ it is either $E\left[\theta_{1} \mid M^{k}\right] \geq E\left[\theta_{2} \mid M^{k}\right]$ or $E\left[\theta_{1} \mid M^{k}\right]<E\left[\theta_{2} \mid M^{k}\right]$.

Define $\mathscr{M}^{+}=\mathrm{U}_{k} M^{k}$ where $E\left[\theta_{1} \mid M^{k}\right]<E\left[\theta_{2} \mid M^{k}\right]$ and $\not \mathscr{M}^{-}=\mathrm{U}_{k} M^{k}$ where $E\left[\theta_{1} \mid M^{k}\right] \geq E\left[\theta_{2} \mid M^{k}\right] . \quad$ Also, define $\quad \mathscr{M}^{++}=M^{+} \cap \mathscr{M}^{+}, \quad \not \mathscr{M}^{+-}=M^{+} \cap \mathscr{M}^{-}$, $\mathscr{M}^{-+}=M^{-} \cap \mathscr{M}^{+}$, and $\mathscr{M}^{--}=M^{-} \cap \mathscr{M}^{-}$.

In a rejection equilibrium, for any given $k v^{k}$, at least one voters always votes against the proposal with any private signal. That is, for some $k$ and $i_{k} \geq n-(q-1), v_{i_{k}}^{k}=(0,0)$. For some $k$ where $E\left[\theta_{n-(q-1)} \mid M^{k}\right]<E\left[\theta_{2} \mid M^{k}\right]$, we should have $E\left[\tilde{u}_{n-(q-1)} \mid M^{k}\right] \leq E\left[\tilde{u}_{i_{k}} \mid M^{k}\right] \leq E\left[\tilde{u}_{i_{k}} \mid M^{k}, \hat{S}_{i_{k}}\left(v_{-i_{k}}^{+}\right)\right]<0$.

Similarly, for some $k$ where $E\left[\theta_{1} \mid M^{k}\right] \geq E\left[\theta_{2} \mid M^{k}\right]$, we should have

$$
E\left[\tilde{u}_{q} \mid M^{k}\right] \leq E\left[\tilde{u}_{i_{k}} \mid M^{k}\right] \leq E\left[\tilde{u}_{i_{k}} \mid M^{k}, \hat{S}_{i_{k}}\left(v_{-i_{k}}^{+}\right)\right]<0 .
$$

Hence there exists a rejection equilibrium with $\left(\left\{\tilde{v}^{+}, \tilde{v}^{-}\right\},\left\{\mathscr{M}^{+}, \mathscr{M}^{-}\right\}\right)$where $\tilde{v}_{i \leq n-(q-1)}^{+}=(0,0), \tilde{v}_{i \Sigma q}^{-}=(0,0)$, and $\tilde{v}_{i s n-(q-1)}^{+}=\tilde{v}_{j<q}^{-}=(1,1)$. 
So, we have $\operatorname{Pr}\left(\mathscr{M}^{+}\right) E\left[\tilde{u}_{n-(q-1)} \mid \mathscr{M}^{+}\right]=\sum_{M^{\prime} \in\left[\tilde{M}^{++}, \tilde{M}^{-+}\right]} \operatorname{Pr}\left(M^{\prime}\right) E\left[\tilde{u}_{n-(q-1)} \mid M^{\prime}\right]<0$, and $\operatorname{Pr}\left(\mathscr{M}^{-}\right) E\left[\tilde{u}_{q} \mid \mathscr{M}^{-}\right]=\sum_{M^{\prime} \in\left[\mathscr{M}^{--}, \mathscr{M}^{+-1}\right.} \operatorname{Pr}\left(M^{\prime}\right) E\left[\tilde{u}_{q} \mid M^{1}\right]<0$.

Since we assume there is no rejection equilibrium with $\left\{M^{+}, M^{-}\right\}$, we should have $\operatorname{Pr}\left(M^{+}\right) \times E\left[\tilde{u}_{n-(q-1)} \mid M^{+}\right]=\sum_{M^{\prime} \in\left[\tilde{Q}^{++}, \mathcal{O}^{+-}\right]} \operatorname{Pr}\left(M^{\prime}\right) E\left[\tilde{u}_{n-(q-1)} \mid M^{\prime}\right]>0, \quad$ and $\operatorname{Pr}\left(M^{-}\right) \times E\left[\tilde{u}_{q} \mid M^{-}\right]=\sum_{M^{\prime} \in\left[M^{--}, M^{-+}\right]} \operatorname{Pr}\left(M^{\prime}\right) E\left[\tilde{u}_{q} \mid M^{\prime}\right]>0$. Hence, we should have

$$
\begin{gathered}
\operatorname{Pr}\left(\mathscr{M}^{-+}\right) E\left[\tilde{u}_{q} \mid \tilde{M}^{-+}\right]>\operatorname{Pr}\left(\mathscr{M}^{+-}\right) E\left[\tilde{u}_{q} \mid \mathscr{M}^{+-}\right] \\
\operatorname{Pr}\left(\mathscr{M}^{+-}\right) E\left[\tilde{u}_{n-(q-1)} \mid \tilde{M}^{+-}\right]>\operatorname{Pr}\left(\mathscr{M}^{-+}\right) E\left[\tilde{u}_{n-(q-1)} \mid \mathscr{M}^{-+}\right]
\end{gathered}
$$

We know, however, that the left hand side of (1.4) is greater than the right hand side of (1.5) and the left hand side of (1.5) is greater than the right hand side of (1.4). Contradiction.

Proof of Proposition 1. Consider any $q$ such that $\frac{n+1}{2} \leq q \leq n$. We first want to show, if $p<\bar{p}(q)$, there exist a rejection equilibrium with the voting strategy specified at Part 1 at the Theorem 1, which proves the existence.

For $M^{+}$, fix $\tilde{v}_{i \leq n-(q-1)}^{+}=(0,0)$ and $\tilde{v}_{i s n-(q-1)}^{+}=(1,1)$. For any $i \leq n-(q-1)$, who is pivotal, we need to show $E\left[\tilde{u}_{i} \mid M^{+}, \hat{S}_{i}\left(\tilde{v}_{-i}\right), s_{i}^{+}\right]<0$, which implies $E\left[\tilde{u}_{i} \mid \hat{S}_{i}\left(\tilde{v}_{-i}\right), s_{i}^{-}\right]<0$.

We know $E\left[\tilde{u}_{i} \mid M^{+}, \hat{S}_{i}\left(\tilde{v}_{-i}\right), s_{i}^{+}\right]=E\left[\tilde{u}_{i} \mid M^{+}, s_{i}^{+}\right]=\frac{4 \gamma_{i}\left(-2 \gamma_{i}(p-1)+p-1\right)-2 p+1}{6\left(4 \gamma_{i}(p-1)-2 p+1\right)}$, and this is decreasing in $\gamma_{i}$, in other words, increasing in $i$. So it is enough to show that

$$
E\left[\tilde{u}_{n-(q-1)} \mid M^{+}, \hat{S}_{n-(q-1)}\left(\tilde{v}_{-(n-(q-1))}\right), s_{n-(q-1)}^{+}\right]<0,
$$

which is guaranteed by the condition $p<\bar{p}(q)$. For $M^{-}$, it is symmetric, so we prove the existence.

Now, we want to show there is no rejection equilibrium if $p \geq \bar{p}(q)$. We prove by contradiction. Suppose there is a rejection equilibrium with a voting strategy $v^{+}$and $v^{-}$. To have any rejection non-trivial equilibrium with the comparative cheap talk, there should be $n-q$ voters who always vote no, i.e. $v_{i}=(0,0)$, and the others should have $(1,0)$ or $(1,1)$. Let's denote $j$ the DM with the lowest 
value of $\gamma$ among DM's who always vote no for $M^{+}$. Then, the index $i$ should be greater than $n-(q-1)$. In order to be an equilibrium strategy, we should have $E\left[\tilde{u}_{j} \mid M^{+}, \hat{S}_{j}\left(v_{-j}\right), s_{j}^{+}\right]<0$. However, we know

$E\left[\tilde{u}_{n-(q-1)} \mid M^{+}, s_{n-(q-1)}^{+}\right] \leq E\left[\tilde{u}_{j} \mid M^{+}, s_{j}^{+}\right] \leq E\left[\tilde{u}_{j} \mid M^{+}, \hat{S}_{j}\left(v_{-j}\right), s_{j}^{+}\right]$,

and $E\left[\tilde{u}_{n-(q-1)} \mid M^{+}, s_{n-(q-1)}^{+}\right] \geq 0$, since $p \geq \bar{p}(q)$. Therefore, $v_{j}^{+}=(0,0)$ cannot be an equilibrium strategy for DM $i$. Contradiction. So, there is no rejection equilibrium with $m *(\theta)$. Furthermore, from Lemma 2, we can show there is no rejection equilibrium with any arbitrary cheap talk strategy $m \in \hat{M}$.

\subsubsection{Unanimity}

Lemma 3 (No more than 2 voters with $\$ \mathrm{v}_{-} \mathrm{i}=(1,0) \$$ )

Consider unanimity rule. When $p>\bar{p}(n)$, with 2-element symmetric partition $M=\left\{M^{+}, M^{-}\right\}$, there cannot be an equilibrium with more than two decision makers with $v_{i}=(1,0)$. In addition, to be sequentially rational strategy profile,

1. If two decision makers have $v_{a}^{+}=v_{b>a}^{+}=(1,0)$ and when $p>\tilde{p}(a)$, then $v_{i}^{+}=(1,1)$ for any $i>b$.

2. If two decision makers have $v_{a}^{-}=v_{b<a}^{-}=(1,0)$ and when $p>\tilde{p}(n-a+1)$, then $v_{i}^{-}=(1,1)$ for any $i<b$.

Proof of Lemma 3.

Since $\gamma_{i}<\gamma_{b}$, we have $E\left[\tilde{u}_{i} \mid M^{+}, s_{i}^{l}\right]>E\left[\tilde{u}_{b} \mid M^{+}, s_{b}^{l}\right]$. (Lemma 1) Therefore,

$$
E\left[\tilde{u}_{i} \mid M^{+}, s_{a}^{h}, s_{b}^{h}, s_{i}^{l}\right] \geq E\left[\tilde{u}_{b} \mid M^{+}, s_{a}^{h}, s_{b}^{h}, s_{b}^{l}\right]=E\left[\tilde{u}_{b} \mid M^{+}, s_{a}^{h}\right] \geq E\left[\tilde{u}_{a} \mid M^{+}, s_{a}^{h}\right] .
$$

For any $p>\tilde{p}(a)$, by construction, $E\left[\tilde{u}_{a} \mid M^{+}, s_{a}^{h}\right] \geq 0$.

So, for any $\gamma_{i}$ we have $E\left[\tilde{u}_{i} \mid M^{+}, s_{a}^{h}, s_{b}^{h}, s_{i}^{l}\right] \geq 0$, which implies $v_{i}=(1,1)$. 
Proof of Proposition 2 Part 1 and 2.

For $i=1$, we have

$E\left[\tilde{u}_{1} \mid M^{+}, \hat{S}_{1}\left(\tilde{v}_{-1}^{+}\right), s_{1}^{h}\right]=E\left[\tilde{u}_{1} \mid M^{+}, s_{2}^{h}, s_{1}^{h}\right] \geq E\left[\tilde{u}_{1} \mid M^{+},, s_{1}^{h}\right] \geq 0$. (Lemma 1)

We also have

$E\left[\tilde{u}_{1} \mid M^{+}, \hat{S}_{1}\left(\tilde{v}_{-1}^{+}\right), s_{1}^{l}\right]=E\left[\tilde{u}_{1} \mid M^{+}, s_{2}^{h}, s_{1}^{l}\right]=\frac{\gamma_{2}\left(-2\left(\gamma_{2}+2\right) p+3 \gamma_{2}+2\right)+2 p-1}{6 \gamma_{2}\left(\gamma_{2}(6 p-5)-2 p+1\right)}$.

The denominator is increasing in $p$, since the partial derivative is $6 \gamma_{2}\left(6 \gamma_{2}-2\right)>0$. Put $p=1$ and we get $6 \gamma_{2}\left(\gamma_{2}-1\right)<0$. So the denominator is negative. The numerator is decreasing in $p$ since the partial derivative is $-2\left(\gamma_{2}-1\right)^{2}<0$. Put $p=1$, we get $\left(\gamma_{2}-1\right)^{2}>0$. So, $E\left[\tilde{u}_{1} \mid M^{+}, \hat{S}_{1}\left(\tilde{v}_{-1}^{+}\right), s_{1}^{l}\right]=E\left[\tilde{u}_{1} \mid M^{+}, s_{2}^{h}, s_{1}^{l}\right] \leq 0$. Therefore, $v_{1}=(1,0)$. Similarly, for $i=2$,

$$
E\left[\tilde{u}_{2} \mid M^{+}, \hat{S}_{2}\left(\tilde{v}_{-2}^{+}\right), s_{2}^{h}\right]=E\left[\tilde{u}_{2} \mid M^{+}, s_{1}^{h}, s_{2}^{h}\right] \geq E\left[\tilde{u}_{2} \mid M^{+}, s_{2}^{h}\right] \geq 0 .(\because \text { Lemma1 })
$$

Also, we have $E\left[\tilde{u}_{2} \mid M^{+}, \hat{S}_{2}\left(\tilde{v}_{-2}^{+}\right), s_{2}^{l}\right]=E\left[\tilde{u}_{2} \mid M^{+}, s_{1}^{h}, s_{2}^{l}\right]=\frac{\left(\gamma_{2}-1\right)^{2}-2\left(\gamma_{2}\left(5 \gamma_{2}-4\right)+1\right) p}{6\left(\gamma_{2}(6 p-1)-2 p+1\right)}$. The denominator is increasing in $p$, since the partial derivative is $6\left(6 \gamma_{2}-2\right)>0$. Put $p=\frac{5}{6}$ and we get $-4+24 \gamma_{2}>0$. So the denominator is positive. The numerator is decreasing in $p$ since the partial derivative is $-10 \gamma_{2}^{2}+8 \gamma_{2}-2<0$. Put $p=\frac{5}{6}$, we get $\frac{2}{3}\left(-11 \gamma_{2}^{2}+7 \gamma_{2}-1\right)<0$. So, $E\left[\tilde{u}_{2} \mid M^{+}, \hat{S}_{2}\left(\tilde{v}_{-2}^{+}\right), s_{2}^{l}\right]=E\left[\tilde{u}_{2} \mid M^{+}, s_{1}^{h}, s_{2}^{l}\right] \leq 0$. Therefore, $v_{2}=(1,0)$.

For any $i>2$, we refer Lemma 3 to prove $v_{i}=(1,1)$.

To economize the notation, define, for all $i \in N, B_{i}^{+} \equiv\left(D_{i}^{h} \cap M^{+}\right) \backslash\left(D_{i-1}^{h} \cap M^{+}\right)$ and $B_{n+1}^{+} \equiv M^{+} \backslash\left(D_{n}^{h} \cap M^{+}\right)$. Similarly, for all $i \in N, B_{i}^{-} \equiv\left(D_{i}^{l} \cap M^{-}\right) \backslash\left(D_{i-1}^{l} \cap M^{-}\right)$ and $B_{n+1}^{-} \equiv M^{-} \backslash\left(D_{n}^{l} \cap M^{-}\right)$. Also denote $B_{i} \equiv B_{i}^{+} \cup B_{i}^{-}$

Proof of Proposition 2 Part 3. We prove by contradiction. Let's suppose there is an equilibrium with $\left(\left\{v^{k}\right\}_{k=1}^{K},\left\{M^{k}\right\}_{k=1}^{K}\right)$ which gives the expert higher payoff. For any $M^{k} \in\left\{M^{k}\right\}_{k=1}^{k}$, it is either $E\left[\theta_{1} \mid M^{k}\right] \geq E\left[\theta_{2} \mid M^{k}\right]$ or $E\left[\theta_{1} \mid M^{k}\right]<E\left[\theta_{2} \mid M^{k}\right]$. 
Define $\not \mathscr{M}^{+}=\mathrm{U}_{k} M^{k}$ where $E\left[\theta_{1} \mid M^{k}\right]<E\left[\theta_{2} \mid M^{k}\right]$ and $\not \mathscr{M}^{-}=\mathrm{U}_{k} M^{k}$ where $E\left[\theta_{1} \mid M^{k}\right] \geq E\left[\theta_{2} \mid M^{k}\right] . \quad$ Also, define $\quad \mathscr{M}^{++}=M^{+} \cap \mathscr{M}^{+}, \quad \mathscr{M}^{+-}=M^{+} \cap \mathscr{M}^{-}$, $\mathscr{M}^{-+}=M^{-} \cap \mathscr{M}^{+}$, and $\mathscr{M}^{--}=M^{-} \cap \mathscr{M}^{-}$.

In an equilibrium with monotonic strategy profile which makes the expert higher payoff, for any given $k v^{k}$, at least three toughest voters need to vote against the proposal with a low private signal. That is, $v_{1}^{k}=v_{2}^{k}=v_{3}^{k}=(1,0)$ where $E\left[\theta_{1} \mid M^{k}\right]<E\left[\theta_{2} \mid M^{k}\right] \quad$ and $\quad v_{n}^{k}=v_{n-1}^{k}=v_{n-2}^{k}=(1,0) \quad$ where $E\left[\theta_{1} \mid M^{k}\right] \geq E\left[\theta_{2} \mid M^{k}\right]$. Moreover, for any $k$, there should be the same number of zeros in a strategy profile $v^{k}$. So, we can rewrite the strategy profile which correspond to the two elements $\mathscr{M}^{+}$and $\mathscr{M}^{-}: \tilde{v}^{+}$and $\tilde{v}^{-}$. Hence, $\tilde{v}_{1}^{+}=\tilde{v}_{2}^{+}=\tilde{v}_{2}^{+}=(1,0)$ and $\tilde{v}_{n}^{-}=\tilde{v}_{n-1}^{-}=\tilde{v}_{n-3}^{-}=(1,0)$.

For DM 3, we should have $E\left[\tilde{u}_{3} \mid \tilde{M}^{+}, s_{1}^{h}, s_{2}^{h}, s_{3}^{l}\right] \leq E\left[\tilde{u}_{3} \mid \tilde{M}^{+}, \hat{S}_{3}\left(\hat{v}_{-3}^{+}\right), s_{3}^{l}\right]<0$ which implies

$$
\begin{aligned}
& \operatorname{Pr}\left(\mathscr{M}^{+}, s_{1}^{h}, s_{2}^{h}, s_{3}^{l}\right) E\left[\tilde{u}_{3} \mid \tilde{M}^{+}, s_{1}^{h}, s_{2}^{h}, s_{3}^{l}\right] \\
& =\sum_{M^{\prime} \in\left[\mathscr{M}^{++}, M^{-+}\right]} \operatorname{Pr}\left(M^{\prime}, s_{1}^{h}, s_{2}^{h}, s_{3}^{l}\right) E\left[\tilde{u}_{3} \mid M^{\prime}, s_{1}^{h}, s_{2}^{h}, s_{3}^{l}\right]<0 .
\end{aligned}
$$

Similarly,

$$
\begin{aligned}
& \operatorname{Pr}\left(\mathscr{M}^{-}, s_{n}^{h}, s_{n-1}^{h}, s_{n-2}^{l}\right) E\left[\tilde{u}_{3} \mid \tilde{M}^{-}, s_{n}^{h}, s_{n-1}^{h}, s_{n-2}^{l}\right] \\
& =\sum_{M^{\prime} \in\left[\tilde{M}^{--}, \mathbb{M}^{+-1}\right]} \operatorname{Pr}\left(M^{\prime}, s_{n}^{h}, s_{n-1}^{h}, s_{n-2}^{l}\right) E\left[\tilde{u}_{n-2} \mid M^{\prime}, s_{n}^{h}, s_{n-1}^{h}, s_{n-2}^{l}\right]<0 .
\end{aligned}
$$

From Lemma 3, we know $\sum_{M^{\prime} \in\left[M^{++}, M^{++-}\right]} \operatorname{Pr}\left(M^{\prime}, s_{1}^{h}, s_{2}^{h}, s_{3}^{h}\right) E\left[\tilde{u}_{3} \mid M^{\prime}, s_{1}^{h}, s_{2}^{h}, s_{3}^{l}\right]>0$, and $\sum_{M^{\prime} \in\left[\mathbb{R}^{--,}, M^{-+}\right]} \operatorname{Pr}\left(M^{\prime}, s_{n}^{h}, s_{n-1}^{h}, s_{n-2}^{l}\right) E\left[\tilde{u}_{n-2} \mid M^{\prime}, s_{n}^{h}, s_{n-1}^{h}, s_{n-2}^{l}\right]>0$.

Hence, we should have

$$
\begin{aligned}
& \operatorname{Pr}\left(\mathscr{M}^{+-}, s_{1}^{h}, s_{2}^{h}, s_{3}^{l}\right) E\left[\tilde{u}_{3} \mid \tilde{M}^{+-}, s_{1}^{h}, s_{2}^{h}, s_{3}^{l}\right] \\
& >\operatorname{Pr}\left(\mathscr{M}^{-+}, s_{1}^{h}, s_{2}^{h}, s_{3}^{l}\right) E\left[\tilde{u}_{3} \mid \mathscr{M}^{-+}, s_{1}^{h}, s_{2}^{h}, s_{3}^{l}\right] \\
& \operatorname{Pr}\left(\mathscr{M}^{-+}, s_{n}^{h}, s_{n-1}^{h}, s_{n-2}^{l}\right) E\left[\tilde{u}_{n-2} \mid \tilde{M}^{-+}, s_{n}^{h}, s_{n-1}^{h}, s_{n-2}^{l}\right] \\
& >\operatorname{Pr}\left(\mathscr{M}^{+-}, s_{n}^{h}, s_{n-1}^{h}, s_{n-2}^{l}\right) E\left[\tilde{u}_{n-2} \mid \tilde{M}^{+-}, s_{n}^{h}, s_{n-1}^{h}, s_{n-2}^{l}\right]
\end{aligned}
$$

Now, we compare the left hand side of (1.6) and the right hand side of (1.7). We decompose $\mathscr{M}^{+-}$into seven regions by defining $\mathscr{M}_{1}^{+-}=\mathscr{M}^{+-} \cap B_{1}^{+}$, $\mathscr{M}_{2}^{+-}=\mathscr{M}^{+-} \cap B_{2}^{+}, \mathscr{M}_{3}^{+-}=\mathscr{M}^{+-} \cap B_{3}^{+}, \mathscr{M}_{4}^{+-}=\mathscr{M}^{+-} \cap\left(\cup_{i=4}^{n-2} B_{i}^{+}\right), \mathscr{M}_{5}^{+-}=\mathscr{M}^{+-} \cap B_{n-1}^{+}$, $\mathscr{M}_{6}^{+-}=\mathscr{M}^{+-} \cap B_{n}^{+}$, and $\mathscr{M}_{7}^{+-}=\mathscr{M}^{+-} \cap B_{n+1}^{+}$. 
We can write

$$
\begin{aligned}
& \operatorname{Pr}\left(\mathscr{M}^{+-}, s_{1}^{h}, s_{2}^{h}, s_{3}^{l}\right) E\left[\tilde{u}_{3} \mid \mathscr{M}^{+-}, s_{1}^{h}, s_{2}^{h}, s_{3}^{l}\right] \\
& =\sum_{t=1}^{7} \operatorname{Pr}\left(\tilde{M}_{t}^{+-}, s_{1}^{h}, s_{2}^{h}, s_{3}^{l}\right) E\left[\tilde{u}_{3} \mid \tilde{M}_{t}^{+-}, s_{1}^{h}, s_{2}^{h}, s_{3}^{l}\right],
\end{aligned}
$$

and

$$
\begin{aligned}
& \operatorname{Pr}\left(\mathscr{M}^{+-}, s_{n}^{h}, s_{n-1}^{h}, s_{n-2}^{l}\right) E\left[\tilde{u}_{n-2} \mid \mathscr{M}^{+-}, s_{n}^{h}, s_{n-1}^{h}, s_{n-2}^{l}\right] \\
& =\sum_{t=1}^{7} \operatorname{Pr}\left(\mathscr{M}_{t}^{+-}, s_{n}^{h}, s_{n-1}^{h}, s_{n-2}^{l}\right) E\left[\tilde{u}_{n-2} \mid \tilde{M}_{t}^{+-}, s_{n}^{h}, s_{n-1}^{h}, s_{n-2}^{l}\right] .
\end{aligned}
$$

Since $\mathscr{M}^{+-} \subset M^{+}$, for any $t, E\left(\tilde{u}_{3} \mid \tilde{M}_{t}^{+-}, s_{1}^{h}, s_{2}^{h}, s_{3}^{l}\right)<E\left(\tilde{u}_{n-2} \mid \tilde{M}_{t}^{+-}, s_{n}^{h}, s_{n-1}^{h}, s_{n-2}^{l}\right)$.

And we know

$$
\begin{aligned}
& \operatorname{Pr}\left(\mathscr{M}_{1}^{+-}, s_{1}^{h}, s_{2}^{h}, s_{3}^{l}\right)=p^{2}(1-p)\left|\mathscr{M}_{1}^{+-}\right|=\operatorname{Pr}\left(\mathscr{M}_{1}^{+-}, s_{n}^{h}, s_{n-1}^{h}, s_{n-2}^{l}\right)=p^{2}(1-p)\left|\mathscr{M}_{1}^{+-}\right| \\
& \operatorname{Pr}\left(\mathscr{M}_{2}^{+-}, s_{1}^{h}, s_{2}^{h}, s_{3}^{l}\right)=p(1-p)^{2}\left|\mathscr{M}_{2}^{+-}\right|=\operatorname{Pr}\left(\mathscr{M}_{2}^{+-}, s_{n}^{h}, s_{n-1}^{h}, s_{n-2}^{l}\right)=p^{2}(1-p)\left|\mathscr{M}_{2}^{+-}\right| \\
& \operatorname{Pr}\left(\mathscr{M}_{3}^{+-}, s_{1}^{h}, s_{2}^{h}, s_{3}^{l}\right)=(1-p)^{3}\left|\mathscr{M}_{3}^{++-}\right| \leq \operatorname{Pr}\left(\mathscr{M}_{3}^{+-}, s_{n}^{h}, s_{n-1}^{h}, s_{n-2}^{l}\right)=p^{2}(1-p)\left|\mathscr{M}_{3}^{+-}\right| \\
& \operatorname{Pr}\left(\mathscr{M}_{4}^{+-}, s_{1}^{h}, s_{2}^{h}, s_{3}^{l}\right)=p(1-p)^{2}\left|\mathscr{M}_{4}^{+-}\right| \leq \operatorname{Pr}\left(\mathscr{M}_{4}^{+-}, s_{n}^{h}, s_{n-1}^{h}, s_{n-2}^{l}\right)=p^{2}(1-p)\left|\mathscr{M}_{4}^{+-}\right| \\
& \operatorname{Pr}\left(\mathscr{M}_{5}^{+-}, s_{1}^{h}, s_{2}^{h}, s_{3}^{l}\right)=p(1-p)^{2}\left|\mathscr{M}_{5}^{+-}\right| \leq \operatorname{Pr}\left(\mathscr{M}_{5}^{+-}, s_{n}^{h}, s_{n-1}^{h}, s_{n-2}^{l}\right)=p^{3}\left|\mathscr{M}_{5}^{+-}\right| \\
& \operatorname{Pr}\left(\mathscr{M}_{6}^{+-}, s_{1}^{h}, s_{2}^{h}, s_{3}^{l}\right)=p(1-p)^{2}\left|\mathscr{M}_{6}^{+-}\right| \leq \operatorname{Pr}\left(\mathscr{M}_{6}^{+-}, s_{n}^{h}, s_{n-1}^{h}, s_{n-2}^{l}\right)=p^{2}(1-p)\left|\mathscr{M}_{6}^{+-}\right| \\
& \operatorname{Pr}\left(\mathscr{M}_{7}^{+-}, s_{1}^{h}, s_{2}^{h}, s_{3}^{l}\right)=p(1-p)^{2}\left|\mathscr{M}_{7}^{+-}\right|=\operatorname{Pr}\left(\mathscr{M}_{7}^{+-}, s_{n}^{h}, s_{n-1}^{h}, s_{n-2}^{l}\right)=p(1-p)^{2}\left|\mathscr{M}_{7}^{+-}\right| .
\end{aligned}
$$

This proves that the left hand side of (1.6) is less than or equal to the right hand side of (1.7). Similarly, we can prove that the right hand side of (1.6) is greater than or equal to the left hand side of (1.7). Contradiction.

\subsubsection{Majority}

Proof of Proposition 3Part 1 and 2. For any $i<q$, DM $i$ is pivotal only when $s_{q}=s_{q}^{l} . \quad$ Since $\quad \gamma_{i}>\gamma_{q}=\frac{1}{2}, \quad E\left[\tilde{u}_{i} \mid M^{+}, s_{q}^{l}, s_{i}^{h}\right]=\frac{1}{6}\left(1-2 \gamma_{i}\right)<0 . \quad$ Moreover, 
$E\left[\tilde{u}_{i} \mid M^{+}, s_{q}^{l}, s_{i}^{l}\right]<E\left[\tilde{u}_{i} \mid M^{+}, s_{q}^{l}, s_{i}^{h}\right]$. Therefore, any DM $i<q$ dose not have incentive to deviate.

For any $i>q$, DM $i$ is pivotal only when $s_{l}=h$. Since $\gamma_{i}<\gamma_{q}=\frac{1}{2}$, $E\left[\tilde{u}_{i} \mid M^{+}, s_{q}^{h}, s_{i}^{l}\right]=\frac{1}{6}\left(1-2 \gamma_{i}\right)>0$. Moreover, $E\left[\tilde{u}_{i} \mid M^{+}, s_{q}^{h}, s_{i}^{h}\right]>E\left[\tilde{u}_{i} \mid M^{+}, s_{q}^{h}, s_{i}^{l}\right]$. Therefore, any DM $i>q$ dose not have incentive to deviate.

Voter $i=q$ is always pivotal, and it is easy to show that he has no incentive to deviate for any $p>\frac{1}{2}: E\left[\tilde{u}_{q} \mid M^{+}, s_{q}^{h}\right]=\frac{2 p-1}{6}>0$ and $E\left[\tilde{u}_{q} \mid M^{+}, s_{q}^{l}\right]=\frac{1-2 p}{6}<0$.

Lemma 4 (Conditional Expectations)
1. $\frac{\partial E\left[\theta_{1} \mid M^{+}, s_{i}^{l}\right]}{\partial \gamma_{i}}<0$ for any $\gamma_{i}<\frac{1}{2}, \frac{\partial E\left[\theta_{1} \mid M^{+}, s_{i}^{i}\right]}{\partial \gamma_{i}}>0$ for any $\gamma_{i}>\frac{2}{3}$
2. $\frac{\partial E\left[\theta_{2} \mid M^{+}, s_{i}^{i}\right]}{\partial \gamma_{i}}>0$ for any $\gamma_{i}<\frac{1}{2}$ and $p>\frac{5}{6}, \frac{\partial E\left[\theta_{2} \mid M^{+}, s_{i}^{i}\right]}{\partial \gamma_{i}}>0$ for any $\gamma_{i}>\frac{2}{3}$
3. $\frac{\partial E\left[\tilde{\gamma}_{j} \mid M^{+}, s_{i}^{i}\right]}{\partial \gamma_{i}}>0$ for any $\gamma_{i}>\frac{1}{2}$ and $\gamma_{j} \leq \frac{1}{2}$
4. $\frac{\partial E\left[\tilde{u}_{j} \mid M^{+}, s_{i}^{i}\right]}{\partial \gamma_{i}}>0$ for any $\gamma_{i}>\frac{1}{2}$ and $\gamma_{j} \leq p$

Proof of Lemma 4.

When $\gamma_{i}<\frac{1}{2}, \frac{\partial E\left[\theta_{1} \mid M^{+}, s_{i}^{i}\right]}{\partial \gamma_{i}}=\frac{2(p-1)(2 p-1)}{3\left(4 \gamma_{i}(p-1)-2 p+3\right)^{2}}$, which is always positive.

When $\gamma_{i}>\frac{1}{2}, \frac{\partial E\left[\theta_{1} \mid M^{+}, s_{i}^{1}\right]}{\partial \gamma_{i}}=\frac{(2 p-1)\left(2\left(6 \gamma_{i}^{2}-4 \gamma_{i}+1\right) p-1\right)}{6 \gamma_{i}^{2}\left(\left(4 \gamma_{i}-2\right) p+1\right)^{2}}$, which is positive when $\gamma_{i} \geq \frac{2}{3}$.

When $\gamma_{i}<\frac{1}{2}, \frac{\partial E\left[\theta_{2} \mid M^{+}, s_{i}^{l}\right]}{\partial \gamma_{i}}=\frac{(2 p-1)\left(4 \gamma_{i}\left(3 \gamma_{i}-4\right)(p-1)+6 p-5\right)}{6\left(\gamma_{i}-1\right)^{2}\left(4 \gamma_{i}(p-1)-2 p+3\right)^{2}}$, which is positive when $p>\frac{5}{6}$.

When $\gamma_{i}>\frac{1}{2}, \frac{\partial E\left[\theta_{2} \mid M^{+}, s_{i}\right]}{\partial \gamma_{i}}=\frac{2 p(2 p-1)}{3\left(\left(4 \gamma_{i}-2\right) p+1\right)^{2}}$, which is always positive.

When $\gamma_{i}>\frac{1}{2}, \frac{\partial E\left[\tilde{\gamma}_{j} \mid M^{+}, s_{i}^{2}\right]}{\partial \gamma_{i}}=\frac{(2 p-1)\left(2 p\left(\gamma_{j}\left(4 \gamma_{i}^{2}-4 \gamma_{i}+1\right)+2 \gamma_{i}^{2}\right)-\gamma_{j}\right)}{6 \gamma_{i}^{2}\left(\left(4 \gamma_{i}-2\right) p+1\right)^{2}}$, which is positive when $\gamma_{j} \leq p$. 
Proof of Proposition 3 Part 3.

First, consider any equilibrium with exactly one voter $i$ with $v_{i}=(1,0)$. In order to be a non-trivial equilibrium, there should be exactly $\frac{n-1}{2}$ number of DM's with $(1,1)$ and $\frac{n-1}{2}$ number of DM's with $(0,0)$. If $i>q$, then the expert's expected payoff would be lower than the characterized equilibrium in the Proposition 3. If $i<q$, any $i \geq q$ should vote for the proposal when he gets a high signal, since

$$
E\left[\tilde{u}_{j} \mid M^{+}, s_{j}^{h}, s_{i}^{l}\right] \geq E\left[\tilde{u}_{q} \mid M^{+}, s_{q}^{h}, s_{i}^{l}\right]>E\left[\tilde{u}_{q} \mid M^{+}, s_{q}^{h}, s_{q}^{l}\right]=E\left[\tilde{u}_{q} \mid M^{+}\right] \quad(\because \text { Lemma4})
$$

So, at least $\frac{n+1}{2}$ number of DM's should have $(1,1)$. Contradiction.

Second, consider any equilibrium with exactly two voters $a$ and $b$ with $v_{a}=v_{b}=(1,0)$. Without loss of generality, assume $\gamma_{a}>\gamma_{b}$. In order to be a non-trivial equilibrium, there should be either exactly $\frac{n-1}{2}$ number of DM's with $(1,1)$ and $\frac{n-1}{2}$ number of DM's with $(0,0)$, or exactly $\frac{n-3}{2}$ number of DM's with $(1,1)$ and $\frac{n+1}{2}$ number of DM's with $(0,0)$. For the prior case, the proposal would be accepted when either one of $a$ and $b$ has a high private signal. So, it is easy to show that the highly biased expert's payoff cannot be higher than the characterized equilibrium in Proposition 3. So, we only focus on the latter case in this proof.

If $\gamma_{b}=\frac{1}{2}$, as shown above, $v_{i}$ should be $(1,1)$ for $\gamma_{i}<\gamma_{b}$, since,

$$
E\left[\tilde{u}_{i} \mid M^{+}, s_{a}^{h}, s_{b}^{h}, s_{i}^{l}\right]>E\left[\tilde{u}_{b} i \mid M^{+}, s_{a}^{h}, s_{b}^{h}, s_{b}^{l}\right]=E\left[\tilde{u}_{b} \mid M^{+}, s_{a}^{h}\right]>E\left[\tilde{u}_{b} \mid M^{+}\right]=0
$$

So, at least $\frac{n-1}{2}$ number of DM's would have $v_{i}=(1,1)$. Contradiction.

If $\gamma_{a}=\frac{1}{2}, v_{b}=(1,1)$. Contradiction.

If both $\gamma_{a}>\gamma_{b}>\frac{1}{2}$, then all other DMs with $\gamma_{i}<\gamma_{a}$ should have $v_{a}=(1,1)$. (Lemma 3) So, more than $\frac{n-3}{2}$ number of DMs have (1,1). Contradiction.

If both $\gamma_{b}<\gamma_{a}<\frac{1}{2}$, then $E\left[\tilde{u}_{b} \mid M^{+}, s_{a}^{h}, s_{b}^{l}\right]>E\left[\tilde{u}_{a} \mid M^{+}, s_{a}^{h}, s_{a}^{l}\right]=E\left[\tilde{u}_{a} \mid M^{+}\right]>0$. So, $v_{b}$ should be $(1,1)$. Contradiction. 
If $\gamma_{a}>\gamma_{q}=\frac{1}{2}>\gamma_{b}$, then any DM $q$ should have $v_{q}=(0,0)$. (If not, then $v_{i \unlhd q}=(1,1)$ except $i=b$. So, there would be at least $\frac{n-1}{2}$ number of DMs with $(1,1)$.) However, $E\left[\tilde{u}_{q} \mid M^{+}, s_{a}^{h}, s_{b}^{h}, s_{q}^{h}\right]>E\left[\tilde{u}_{q} \mid M^{+}, s_{q}^{h}\right]>0$. So, contradiction.

Third, consider any equilibrium with three DMs $a, b$ and $c$ with $v_{a}=v_{b}=v_{c}=(1,0)$. Without loss of generality, $\gamma_{a}>\gamma_{b}>\gamma_{c}$. Similar to the previous case, the case where the proposal will be approved with one or two of those three DMs cannot be better for the expert. So, we just focus on the case where the project would be approved only with the supports of all three DMs $a$, $b$ and $c$. Then, by Lemma 3 , we can show the voting strategy of DM $c$ should be $v_{c}=(1,1)$. Contradiction.

\subsection{Surplus Maximizing Expert}

Proof of Proposition 4. Consider a voting profile $\hat{v}\left(T^{+}\right)$where, given $T^{+}$, DMs vote for the proposal if and only if $i \leq \kappa(q)$ or $i \leq n-\kappa(q)+1$. All of them are pivotal with a positive probability, but all others are not. For $i \leq \kappa(q)$ or $i \leq n-\kappa(q)+1$, if $E\left[\tilde{u}_{i} \mid \hat{T}^{+}, \hat{S}_{i}\left(\hat{v}_{-i}^{+}\right), s_{i}^{l}\right] \geq 0$, then they have no incentive to deviate. For any $i \leq \frac{n+1}{2}$,

$$
E\left[\tilde{u}_{i} \mid \hat{T}^{+}, \hat{S}_{i}\left(\hat{v}_{-i}\right), s_{i}^{l}\right]=E\left[\tilde{u}_{i} \mid T^{+}, s_{i}^{l}\right]=\frac{4 \gamma_{i}^{2}+\left(-8 \gamma_{i}^{2}+4 \gamma_{i}-2\right) p+1}{12 \gamma_{i}-12 p+6} .
$$

Equation 1.8, which is increasing in $i$, is greater than or equal to 0 when $p \leq \frac{1}{2}+\frac{\gamma_{i}}{4 \gamma_{i}^{2}-2 \gamma_{i}+1}$. The symmetric argument applies for $i>\frac{n+1}{2}$. So, if $p<\hat{p}(q)$, all DM $i$ do not have any incentive to deviate.

Now consider a voting profile $\hat{v}\left(T^{-}\right)$where, given $T^{-}$, all DMs vote for the proposal except $i=\frac{n+1}{2}$. It is obvious that the only pivotal DM $i=\frac{n+1}{2}$ has $E\left[\tilde{u}_{i} \mid \hat{T}^{-}, \hat{s}_{i}\left(\hat{v}_{-i}^{+}\right), s_{i}^{h}\right] \leq 0$. So, no one has any incentive to deviate. This is true for any $p>\frac{1}{2}$. Therefore, we prove $\hat{v}$ is a non-trivial equilibrium profile.

Now suppose $p<\hat{p}(n)$. Given $T^{+}, E\left[\tilde{u}_{i} \mid T^{+}, s_{i}^{l}\right]$ for all $i$. Therefore, when 
$p<\hat{p}(n)$, there exists a sincere voting equilibrium with $v\left(T^{+}, s_{i}\right)=1$ and $v\left(T^{-}, s_{i}\right)=0$ for all $i$ and $s_{i}$.

Proof of Proposition 5.

We are going to show that there is an equilibrium with the overall cheap talk $t^{*}(\theta)$ and a voting strategy $\left\{\tilde{v}^{+}, \tilde{v}^{-}\right\}$such that for $T^{+}, \tilde{v}_{1}^{+}=\tilde{v}_{n}^{+}=(1,0)$ and $\tilde{v}_{1<i<n}^{+}=(1,1)$ and for $T^{-}, \tilde{v}_{i \neq \frac{n+1}{2}}^{-}=(1,1)$ and $\frac{\tilde{v}_{\frac{n+1}{2}}^{-}=(0,0)}{\text {. }}$.

Consider a voting profile $\tilde{v}\left(T^{+}\right)$where, given $T^{+}$, DMs with $1<i<n$ always vote for the proposal and DM with $i=1$ or $n$ have $v_{i}=(1,0)$. For $1<i<n$, if $E\left[\tilde{u}_{i} \mid T^{+}, \hat{S}_{i}\left(\tilde{v}_{-i}^{+}\right), s_{i}^{l}\right] \geq 0$, then the DMs have no incentive to deviate. For any $1<i<\frac{n+1}{2}$,

$$
\begin{aligned}
& E\left[\tilde{u}_{i} \mid T^{+}, \hat{S}_{i}\left(\tilde{v}_{-i}\right), s_{i}^{l}\right]=E\left[\tilde{u}_{i} \mid T^{+}, s_{n}^{h}, s_{i}^{l}\right] \\
& =\frac{\gamma_{i}+\gamma_{1}^{2}\left(4 \gamma_{i}^{2}+\left(-8 \gamma_{i}^{2}+4 \gamma_{i}-2\right) p+1\right)+4 \gamma_{i} \gamma_{1}(2 p-1)-2 \gamma_{i} p}{6 \gamma_{1}\left(\gamma_{1}+2 \gamma_{i}\left(\gamma_{1}+2 p-1\right)-2 \gamma_{1} p\right)} .
\end{aligned}
$$

The above equation is positive for any $p>\frac{1}{2}$ and $\gamma_{i}<\gamma_{1}$. The symmetric argument applies for $i>\frac{n+1}{2}$.

For DM with $i=1$, if $E\left[\tilde{u}_{1} \mid T^{+}, \hat{S}_{1}\left(\tilde{v}_{-1}^{+}\right), s_{1}^{l}\right] \leq 0$, then the DM have no incentive to deviate.

$$
\begin{aligned}
& E\left[\tilde{u}_{1} \mid T^{+}, \hat{S}_{1}\left(\tilde{v}_{-1}^{+}\right), s_{1}^{l}\right] \\
& =E\left[\tilde{u}_{1} \mid T^{+}, s_{n}^{h}, s_{1}^{l}\right]=\frac{4 \gamma_{1}^{3}-3 \gamma_{1}+\left(4\left(\gamma_{1}-2\right) \gamma_{1}+2\right) p^{2}+\left(-8 \gamma_{1}^{3}+10 \gamma_{1}-3\right) p+1}{6 \gamma_{1}\left(2 \gamma_{1}+4\left(\gamma_{1}-1\right)(p-1) p-1\right)},
\end{aligned}
$$

which is not greater than zero when

$$
p \geq \underline{p} \equiv \frac{8 \gamma_{1}^{3}-\sqrt{64 \gamma_{1}^{6}-64 \gamma_{1}^{5}-32 \gamma_{1}^{4}+64 \gamma_{1}^{3}-12 \gamma_{1}^{2}-4 \gamma_{1}+1}-10 \gamma_{1}+3}{2\left(4 \gamma_{1}^{2}-8 \gamma_{1}+2\right)} .
$$

We can show that $\hat{p}(n)>\underline{p}$. So, DM 1 does not have any incentive to deviate. The symmetric argument applies for DM $n$. The part with $T^{-}$is pretty obvious. Therefore, we show the existence. Furthermore, this proof already shows that there cannot be any other non-trivial equilibrium with a symmetric and monotonic voting profile. 


\section{Equilibrium Property}

The following proposition formally provides rationale behind our restricted attention an equilibrium with voting strategies which is monotonic in the corresponding DMs' private signals on equilibrium paths. We denote $\hat{S}_{i}\left(v_{-i}^{k}\right) \subseteq \times_{j \neq i} S_{j}$ be the set of events where DM $i$ is pivotal under $v_{-i}^{k}=\left(v_{j}^{k}\right)_{j \neq i}$. Then, given any message $M^{k}$, strategy profile $v^{k}$ and signal $s_{i}$, the difference between vote for and against the proposal would be

$$
\begin{aligned}
& E\left(u_{i}\left(v_{i}\left(s_{i}\right)=1\right) \mid M^{k}, v_{-i}^{k}, s_{i}\right)-E\left(u_{i}\left(v_{i}\left(s_{i}\right)=0\right) \mid M^{k}, v_{-i}^{k}, s_{i}\right) \\
& =\operatorname{Pr}\left(\hat{S}_{i}\left(v_{-i}^{k}\right) \mid M^{k}, s_{i}\right) E\left(\tilde{u}_{i} \mid M^{k}, \hat{S}_{i}\left(v_{-i}^{k}\right), s_{i}\right),
\end{aligned}
$$

where $\hat{S}_{i}\left(v_{-i}^{k}\right) \subseteq \times_{j \neq i} S_{j}$ is the set of events where DM $i$ is pivotal under $v_{i}^{k}$.

So, if $E\left(\tilde{u}_{i} \mid M^{k}, \hat{S}_{i}\left(v_{-i}^{k}\right), s_{i}\right)>0$, then $v_{i}\left(M^{k}, s_{i}\right)=1$ is a strictly dominant strategy. Moreover, $E\left(\tilde{u}_{i} \mid M^{k}, \hat{S}_{i}\left(v_{-i}^{k}\right), s_{i}\right)$ is non-decreasing in $s_{i}$, a DM's voting strategy should be non-decreasing in his own private signal if his probability of being pivotal is positive.

Proposition 6 (Strategy of a Pivotal DM)

In an equilibrium with a partition $\left\{M^{k}\right\}_{k=1}^{K}$ and a corresponding strategy profile

$\left\{v^{k}\right\}_{k=1}^{k}$, if any decision maker $i$ is pivotal with positive probability given a message $M^{k}$ and the corresponding strategy profile $v^{k}$, then $v_{i}\left(M^{k}, h\right) \geq v_{i}\left(M^{k}, l\right)$.

Proof of Proposition 6.

Since DM $i$ is pivotal with positive probability under a message $M^{k}$ and the corresponding strategy profile $v^{k}, \quad \hat{S}_{i}\left(v_{-i}^{k}\right) \neq \emptyset$. So, it is clear that $E\left[\tilde{u}_{i} \mid M^{k}, \hat{S}_{i}\left(v_{-i}^{k}\right), s_{i}^{h}\right] \geq E\left[\tilde{u}_{i} \mid M^{k}, \hat{S}_{i}\left(v_{-i}^{k}\right), s_{i}^{l}\right]$, which proves the Proposition. 


\section{Babbling Equilibrium}

Assumption 1 (Two extreme decision makers) In the group of decision makers, there always exists two extreme types of decision makers with $\gamma_{1}=1$ and $\gamma_{n}=0$.

Proposition 7 (The Existence of Babbling Equilibrium)

Consider $q$-majority, $\frac{n+1}{2} \leq q \leq n$. For any value of $p>\frac{1}{2}$, there always exists a babbling equilibrium. Specifically, there is a non-trivial babbling equilibrium with

$$
v_{i}\left(s_{i}^{h}, s_{i}^{l}\right)= \begin{cases}(1,0) & \text { if } i \leq n-q+1 \text { or } i \geq q, \\ (1,1) & \text { o.w.. }\end{cases}
$$

Proof of Proposition 7.

For any the pivotal event of DM $l, E_{l}$, and $B_{i} \in\left\{B_{i}^{+}, B_{i}^{-}\right\}$

$$
\operatorname{Pr}\left[\theta \in B_{i} \mid E_{l}\right]=\frac{\operatorname{Pr}\left[\bar{E}_{l} \mid \theta \in \bar{B}_{i} \operatorname{Pr}\left[\theta \in \bar{B}_{i}\right]\right.}{\sum_{j=1}^{n+1} \operatorname{Pr}\left[E_{l} \mid \theta \in \bar{B}_{j}\right] \operatorname{Pr}\left[\theta \in B_{j}\right]} .
$$

By construction

$$
\operatorname{Pr}\left[\theta \in B_{i}^{+}\right]=\operatorname{Pr}\left[\theta \in B_{i}^{-}\right] \text {. }
$$

We just focus on the case when $l \leq n-q+1$, since the other case, $l \geq q$, is just symmetric. Define $\tilde{n} \equiv \tilde{n}(n, q)=n-q+1$ and $\bar{a} \equiv \bar{a}(l, n, q)$

$$
\begin{aligned}
& \bar{a} \equiv \bar{a}(l, n, q, i)= \begin{cases}i-1 & i \leq l, \\
i-2 & l<i \leq \tilde{n}, \\
\tilde{n}-1 & \tilde{n}<i \leq q, \\
(\tilde{n}-1)+(i-q) & i>q .\end{cases} \\
& \operatorname{Pr}\left[E_{l} \mid \theta \in B_{i}^{+}\right]=\sum_{a=0}^{a}\left(\begin{array}{l}
\bar{a} \\
a
\end{array}\right)(1-p)^{a} p^{a-a}\left(\begin{array}{l}
2 \tilde{n}-1-\bar{a} \\
\tilde{n}-a
\end{array}\right) p^{\tilde{n}-a}(1-p)^{\tilde{n}-1-a+a} \\
& =[p(1-p)]^{\hat{n}} \sum_{a=0}^{a}\left(\begin{array}{l}
\bar{a} \\
a
\end{array}\right)\left(\begin{array}{l}
2 \tilde{n}-1-\bar{a} \\
\tilde{n}-a
\end{array}\right) p^{a-2 a}(1-p)^{-1-a+2 a}
\end{aligned}
$$




$$
\begin{aligned}
& \operatorname{Pr}\left[E_{l} \mid \theta \in B_{i}^{-}\right]=\sum_{a=0}^{a}\left(\begin{array}{l}
\bar{a} \\
a
\end{array}\right) p^{a}(1-p)^{a-a}\left(\begin{array}{l}
2 \tilde{n}-1-\bar{a} \\
\tilde{n}-a
\end{array}\right)(1-p)^{\tilde{n}-a} p^{\tilde{n}-1-a+a} \\
& =[p(1-p)]^{\tilde{n}} \sum_{a=0}^{a}\left(\begin{array}{l}
\bar{a} \\
a
\end{array}\right)\left(\begin{array}{l}
2 \tilde{n}-1-\bar{a} \\
\tilde{n}-a
\end{array}\right) p^{-1-\bar{a}+2 a}(1-p)^{\bar{a}-2 a}
\end{aligned}
$$

By construction, if $B_{i}^{+}$is in $D_{i}^{h}$, then $B_{i}^{-}$is in $D_{i}^{l}$, and vice versa. In order to show that $v_{l}=(1,0)$ is the equilibrium strategy, it is enough to show that, for all $i \in N \cup\{n+1\}$,

$$
p \times \operatorname{Pr}\left[E_{l} \mid \theta \in B_{i}^{+}\right]>(1-p) \times \operatorname{Pr}\left[E_{l} \mid \theta \in B_{i}^{-}\right]
$$

and

$$
(1-p) \times \operatorname{Pr}\left[E_{l} \mid \theta \in B_{i}^{+}\right]<p \times \operatorname{Pr}\left[E_{l} \mid \theta \in B_{i}^{-}\right] .
$$

To economize the notion, let $C(a) \equiv\left(\begin{array}{l}\bar{a} \\ a\end{array}\right)$ and $D(a) \equiv\left(\begin{array}{l}2 \tilde{n}-1-\bar{a} \\ \tilde{n}-a\end{array}\right)$. Since $\frac{2 \pi-1-\bar{a}}{2}=\tilde{n}-\frac{a+1}{2}, D(a)=D(\bar{a}-a+1)$. Then,

$$
\begin{aligned}
& p \times \frac{P r\left[E_{l} \mid \theta \in B_{i}^{+}\right]}{[p(1-p)]^{n}}-(1-p) \times \frac{P r\left[E_{l} \mid \theta \in B_{i}^{-}\right]}{[p(1-p)]^{n}} \\
& =\sum_{a=1}^{\bar{\varepsilon} \frac{a}{2} a} D(a)\left[C(a)\left\{\left(\frac{p}{1-p}\right)^{a-2 a+1}-\left(\frac{1-p}{p}\right)^{a-2 a+1}\right\}\right. \\
& \left.+C(\bar{a}-a+1)\left\{\left(\frac{p}{1-p}\right)^{-(a-2 a+1)}-\left(\frac{1-p}{p}\right)^{-(a-2 a+1)}\right\}\right] \\
& +C(0) D(0)\left\{\left(\frac{p}{1-p}\right)^{G+1}-\left(\frac{1-p}{p}\right)^{G+1}\right\} \\
& +C\left(\frac{a+1}{2}\right) D\left(\frac{a+1}{2}\right)\left\{\left(\frac{p}{1-p}\right)^{0}-\left(\frac{1-p}{p}\right)^{0}\right\} \\
& =\sum_{a=1}^{\bar{\varepsilon} \frac{a}{2} a} D(a)\{C(a)-C(\bar{a}-a+1)\}\left\{\left(\frac{p}{1-p}\right)^{a-2 a+1}-\left(\frac{1-p}{p}\right)^{a-2 a+1}\right\} \\
& +C(0) D(0)\left\{\left(\frac{p}{1-p}\right)^{a+1}-\left(\frac{1-p}{p}\right)^{a+1}\right\}
\end{aligned}
$$

We know $C(a)>C(\bar{a}-a+1)$ and $p>1-p$. Hence, the above equation is positive.

We know $C(a)=C(\bar{a}-a)$.

$$
\begin{aligned}
& (1-p) \times \frac{p_{r}\left[E_{l} \mid \theta \in \bar{B}_{i}^{+}\right]}{[p(1-p)]^{n}}-p \times \frac{p r\left[E_{l} \mid \theta \in B_{i}^{-}\right]}{[p(1-p)]^{n}} \\
& =\sum_{a=0}^{\varepsilon \frac{a-1}{2}} C(a)\left[D(a)\left\{\left(\frac{p}{1-p}\right)^{\alpha-2 a}-\left(\frac{1-p}{p}\right)^{\alpha-2 a}\right\}\right.
\end{aligned}
$$




$$
\begin{aligned}
& \left.+D(\bar{a}-a)\left\{\left(\frac{p}{1-p}\right)^{-(a-2 a)}-\left(\frac{1-p}{p}\right)^{-(a-2 a)}\right\}\right] \\
& +C\left(\frac{\bar{a}}{2}\right) D\left(\frac{a}{2}\right)\left\{\left(\frac{p}{1-p}\right)^{0}-\left(\frac{1-p}{p}\right)^{0}\right\} \\
& =\sum_{a=0}^{\bar{\varepsilon} \frac{a-1}{2}} C(a)\{D(a)-D(\bar{a}-a)\}\left\{\left(\frac{p}{1-p}\right)^{a-2 a}-\left(\frac{1-p}{p}\right)^{a-2 a}\right\}
\end{aligned}
$$

Since $\frac{2 n-1-\bar{a}}{2}=\tilde{n}-\frac{a+1}{2}, D(a)<D(\bar{a}-a)$. Hence, the above equation is negative.

Therefore, we prove $v_{l}=(1,0)$ is the equilibrium strategy for any $l \leq n-q+1$ and $l \geq q$.

Now, we are going to prove $v_{l}=(1,1)$ for any $n-q+1<l<q$.

$$
\tilde{a} \equiv \tilde{a}(l, n, q, i)= \begin{cases}i-1 & i \leq \tilde{n}, \\ \tilde{n} & \tilde{n}<i \leq q . \\ \tilde{n}+(i-q) & i>q .\end{cases}
$$

For any $n-q+1<l<q$,

$$
\begin{aligned}
& \operatorname{Pr}\left[E_{l} \mid \theta \in B_{i}^{+}\right]=\sum_{a=0}^{\alpha}\left(\begin{array}{l}
\tilde{a} \\
a
\end{array}\right)(1-p)^{a} p^{\tilde{\alpha}-a}\left(\begin{array}{l}
2 \tilde{n}-\tilde{a} \\
\tilde{n}+1-a
\end{array}\right) p^{\tilde{n}+1-a}(1-p)^{\tilde{n}-1-\alpha+a} \\
& =[p(1-p)]^{\tilde{n}} \sum_{a=0}^{\alpha}\left(\begin{array}{l}
\tilde{a} \\
a
\end{array}\right)\left(\begin{array}{l}
2 \tilde{n}-\tilde{a} \\
\tilde{n}+1-a
\end{array}\right) p^{1+\alpha-2 a}(1-p)^{-1-\alpha+2 a} \\
& \operatorname{Pr}\left[E_{l} \mid \theta \in B_{i}^{-}\right]=\sum_{a=0}^{a}\left(\begin{array}{l}
\tilde{a} \\
a
\end{array}\right) p^{a}(1-p)^{a-a}\left(\begin{array}{l}
2 \tilde{n}-\tilde{a} \\
\tilde{n}+1-a
\end{array}\right)(1-p)^{\tilde{n}+1-a} p^{\tilde{n}-1-\tilde{a}+a} \\
& =[p(1-p)]^{\tilde{n}} \sum_{a=0}^{\alpha}\left(\begin{array}{l}
\tilde{a} \\
a
\end{array}\right)\left(\begin{array}{l}
2 \tilde{n}-\tilde{a} \\
\tilde{n}+1-a
\end{array}\right) p^{-1-\tilde{a}+2 a}(1-p)^{1+\alpha-2 a}
\end{aligned}
$$

By construction, $B_{i}^{+} \subset D_{l}^{h}$ for all $i \leq l$ and $l$. Moreover, $B_{i}^{-} \subset D_{l}^{l}$ for all $i \geq n-q+1$ and $l$. For any $B_{i}^{+}$or $B_{i}^{-}$such that $n-q+1<i<q, D_{l}^{h}$ and $D_{l}^{h}$ have same posterior probabilities and proportions. Hence, it is enough to show that, for all $i \leq l$ and $l$ such that $n-q+1<l<q$,

$$
(1-p) \times \operatorname{Pr}\left[E_{l} \mid \theta \in B_{i}^{+}\right] \geq p \times \operatorname{Pr}\left[E_{l} \mid \theta \in B_{i}^{-}\right]
$$

which implies

$$
\begin{aligned}
& p \times \operatorname{Pr}\left[E_{l} \mid \theta \in B_{i}^{+}\right] \geq(1-p) \times \operatorname{Pr}\left[E_{l} \mid \theta \in B_{i}^{-}\right] . \\
& (1-p) \times \frac{\operatorname{Pr}\left[E_{l} \mid \theta \in B_{i}^{+}\right]}{[p(1-p)]^{n}}-p \times \frac{\operatorname{Pr}\left[E_{l} \mid \theta \in B_{i}^{-}\right]}{[p(1-p)]^{n}}
\end{aligned}
$$




$$
\begin{aligned}
& =\sum_{a=0}^{a}\left(\begin{array}{l}
\tilde{a} \\
a
\end{array}\right)\left(\begin{array}{l}
2 \tilde{n}-\tilde{a} \\
\tilde{n}+1-a
\end{array}\right)\left[(1-p)\left(\frac{p}{1-p}\right)^{1+a-2 a}-p\left(\frac{1-p}{p}\right)^{1+a-2 a}\right] \\
& =p \sum_{a=0}^{a}\left(\begin{array}{l}
\tilde{a} \\
a
\end{array}\right)\left(\begin{array}{l}
2 \tilde{n}-\tilde{a} \\
\tilde{n}+1-a
\end{array}\right)\left[\left(\frac{p}{1-p}\right)^{a-2 a}-\left(\frac{1-p}{p}\right)^{1+a-2 a}\right] \\
& =p \sum_{a=0}^{\square \frac{a}{2} a}\left(\begin{array}{l}
\tilde{a} \\
a
\end{array}\right)\left(\begin{array}{l}
2 \tilde{n}-\tilde{a} \\
\tilde{n}+1-a
\end{array}\right)\left[\left\{\left(\frac{p}{1-p}\right)^{a-2 a}-\left(\frac{1-p}{p}\right)^{1+a-2 a}\right\}\right. \\
& +\left\{\left(\frac{p}{1-p}\right)^{-(a-2 a)}-\left(\frac{1-p}{p}\right)^{1-(a-2 a)}\right\} \\
& =p \sum_{a=0}^{\square \frac{a}{2} a}\left(\begin{array}{l}
\tilde{a} \\
a
\end{array}\right)\left(\begin{array}{l}
2 \tilde{n}-\tilde{a} \\
\tilde{n}+1-a
\end{array}\right)\left[\left\{\left(\frac{p}{1-p}\right)^{a-2 a}-\left(\frac{1-p}{p}\right)^{1+a-2 a}\right\}\right. \\
& \left.+\left\{\left(\frac{1-p}{p}\right)^{a-2 a}-\left(\frac{p}{1-p}\right)^{(a-2 a)-1}\right\}\right] \\
& =p \sum_{a=0}^{\square \frac{a}{2} a}\left(\begin{array}{l}
\tilde{a} \\
a
\end{array}\right)\left(\begin{array}{l}
2 \tilde{n}-\tilde{a} \\
\tilde{n}+1-a
\end{array}\right)\left[\left\{\left(\frac{p}{1-p}\right)^{a-2 a}-\left(\frac{p}{1-p}\right)^{(a-2 a)-1}\right\}\right. \\
& \left.+\left\{\left(\frac{1-p}{p}\right)^{a-2 a}-\left(\frac{1-p}{p}\right)^{1+a-2 a}\right\}\right]
\end{aligned}
$$

Since $p>1-p$, the above equation is positive. Therefore, we prove $v_{l}=(1,1)$ for any $n-q+1<l<q$

Lemma 5 (Monotonic voting strategy in an equilibrium)

Consider unanimity, $q=n$, if there exists a non-trivial equilibrium $\left\{\left(M^{k}, v^{k}\right)\right\}_{k=1}^{k}$ with a positive probability of approval, then for any $i$ and $k$, $v_{i}\left(M^{k}, h\right)=1 \geq v_{i}\left(M^{k}, l\right)$.

Lemma 6 (Babbling equilibrium voting strategy)

Consider unanimity $q=n$. In a babbling equilibrium with $v$, for any $i$, $v_{i}^{h}=1$.

Proof of Lemma 6.

For any $v_{-i}$ which makes DM $i$ pivotal,

$$
E\left[\tilde{u}_{i} \mid \hat{S}_{i}\left(v_{-i}\right), s_{i}^{h}\right] \geq E\left[\tilde{u}_{i} \mid s_{i}^{h}\right]>0
$$


Lemma 7 (Existence of a babbling equilibrium)

Suppose Assumption 1 holds. Consider unanimity, $q=n$. There always exists a babbling equilibrium with $v=(1,0,1,1, \ldots 1,1,1,0)$.

Proof of Lemma 7.

From Lemma 6, we know $v_{i}^{h}=1$ for any $i$.

Since the indifferent lines of DM 1 and DM $n$ are orthogonal, for any $s_{1}$ and $s_{n}$

$$
E\left[\tilde{u}_{1} \mid \hat{S}_{1}\left(v_{-1}\right), s_{1}\right]=E\left[\tilde{u}_{1} \mid s_{1}, s_{n}\right]=E\left[\tilde{u}_{1} \mid s_{1}\right] .
$$

and

$$
E\left[\tilde{u}_{n} \mid \hat{S}_{n}\left(v_{-n}\right), s_{n}\right]=E\left[\tilde{u}_{n} \mid s_{1}, s_{n}\right]=E\left[\tilde{u}_{n} \mid s_{n}\right] .
$$

So,

$$
E\left[\tilde{u}_{1} \mid s_{n}, s_{1}^{l}\right]=E\left[\tilde{u}_{1} \mid s_{1}^{l}\right]<0,
$$

and

$$
E\left[\tilde{u}_{n} \mid s_{1}, s_{n}^{l}\right]=E\left[\tilde{u}_{n} \mid s_{n}^{l}\right]<0 .
$$

For any $i$ such that $1<i \leq \frac{n+1}{2}$,

$$
E\left[\tilde{u}_{i} \mid \hat{S}_{i}\left(v_{-i}\right), s_{i}^{l}\right]=E\left[\tilde{u}_{i} \mid s_{1}^{h}, s_{n}^{h}, s_{i}^{l}\right]=\frac{\left(1-\gamma_{i}\right)\left(1-7 \gamma_{i}\right)(2 p-1)}{6\left(1-2\left(1-\gamma_{i}\right) p-5 \gamma_{i}\right)}>0
$$

Similarly, for any $i$ such that $\frac{n+1}{2}<i<n$, we can show that

$$
E\left[\tilde{u}_{i} \mid \hat{S}_{i}\left(v_{-i}\right), s_{i}^{l}\right]=E\left[\tilde{u}_{i} \mid s_{1}^{h}, s_{n}^{h}, s_{i}^{l}\right]>0 .
$$

Lemma 8 (Babbling equilibrium property)

Suppose Assumption 1 holds. Consider unanimity, $q=n$. There is no symmetric babbling equilibrium with more than 2 decision makers with $v_{i}=(1,0)$.

Proof. Suppose there exists a symmetric equilibrium with $\hat{v}_{i}=\hat{v}_{n-i+1}=(1,0)$ and $\hat{v}_{j}=\hat{v}_{n-j+1}=(1,0)$, which is different from the voting strategy from Lemma $7, v=(1,0,1,1, \ldots 1,0)$. By construction,

$$
E\left[\tilde{u}_{n-i+1} \mid \hat{S}_{n-i+1}\left(\hat{v}_{-(n-i+1)}\right), s_{n-i+1}^{l}\right]>E\left[\tilde{u}_{n-i+1} \mid \hat{S}_{n-i+1}\left(v_{-(n-i+1)}\right), s_{n-i+1}^{l}\right],
$$

and from Lemma 7, we know 


$$
E\left[\tilde{u}_{n-i+1} \mid \hat{S}_{n-i+1}\left(v_{-(n-i+1)}\right), s_{n-i+1}^{l}\right]>0 .
$$

Therefore, $\hat{v}_{n-i+1}$ should be $(1,1)$. So, contradiction.

Lemma 9 (Expert optimal babbling equilibrium)

Suppose Assumption 1 holds. Consider unanimity, $q=n$. If there exists a symmetric babbling equilibrium with $v_{i>1}=v_{n-i+1}=(1,0)$ and $v_{j \neq i}=(1,1)$, then the expert's payoff is less than $\frac{3}{4}$.

Proof of Lemma 9.

$$
\begin{aligned}
& \operatorname{Pr}[\text { approval }]=\frac{1}{4} p^{2}+2 \times \sum_{j=2}^{i}\left|B_{j}^{+}\right| p^{2}+2 \times \sum_{j=i+1}^{n-i+1}\left|B_{j}^{+}\right| p(1-p) \\
& +\left\{1-\left(\frac{1}{4}+2 \times \sum_{j=2}^{n-i+1}\left|B_{j}^{+}\right|\right)\right\}(1-p)^{2} \\
& =\frac{1}{4 \gamma_{i}} p^{2}+\left(1-\frac{1}{2 \gamma_{i}}\right) p(1-p)+\frac{1}{4 \gamma_{i}}(1-p)^{2} \\
& =\frac{1}{4 \gamma_{i}}\left(1+4\left(\gamma_{i}-1\right) p(1-p)\right) \geq \frac{1}{4} \\
\text { So, } E & {\left[u^{\varepsilon} \mid v\right] \leq \frac{3}{4} . }
\end{aligned}
$$

Proof of the Existence of a babbling equilibrium under unanimity.

Lemma 6 to 9 prove the existence.

\section{Extra Propositions and Lemmas}

\section{Lemma 10}

Suppose Assumption 1 hold. Consider the unanimity rule. If $p>\frac{5}{6}$, the expert optimal 2-element partition equilibrium characterized in Proposition 2 is better for the expert than the optimal symmetric babbling equilibrium.

Proof. In the equilibrium specified in Proposition 2,

$$
E\left[u^{e}(v \mid \theta)\right]=1-\frac{1}{4}\left[p^{2}+(1-p)\left\{3(1-p)-(1-5 p) \frac{1}{\gamma_{2}}\right\}\right] \geq \frac{3}{4} .
$$




\section{Lemma 11}

Suppose Assumption 1 holds. Consider the unanimity rule, $q=n$. The equilibrium characterized in Proposition 2 gives the expert a weakly higher payoff than any other equilibrium with a finer partition $\left\{M^{k}\right\}_{k=1}^{K} \leq\left\{M^{+}, M^{-}\right\}$.

\section{Proof of Lemma 11.}

First, we prove the optimality among 2-element symmetric partition equilibrium.

We know there cannot be more than 3 zeros in an equilibrium strategy $v$.

(Lemma 3) Moreover, any other 2-element symmetric partition equilibrium with two zeros in $v$ is worse for the expert than the equilibrium characterized in Proposition 2, since the expert's ex ante expected payoff would decrease if the index of either one of DM who has $v_{i}=(1,0)$ increases. Hence, there is no 2-element symmetric partition equilibrium with other voting strategy profile that grants the expert a higher payoff than with $\tilde{v}$.

Now, we prove the dominance over the finer partition equilibrium. First of all, there cannot be any rejection equilibrium with a finer partition. (Since, if there exists a rejection equilibrium with a finer partition, from Lemma 2, there should be a rejection equilibrium with the 2-element partition.)

Second, for any partition equilibrium with positive probability of approval, $M^{k} \cap D^{1} \neq \varnothing$, and there should be the same number of zeros. (If not, for any $\theta \in D^{1}$, one is better than the other, so the message is not credible.)

Now, suppose there is any other non-trivial equilibrium with a finer partition and a voting strategy $v^{\prime}$. If $v^{\prime}=\hat{v}$, then the payoff is the same with the characterized equilibrium.

Suppose $v^{\prime} \neq \hat{v}$. If there is one zero, then the payoff cannot be higher than the 2-element partition equilibrium. (The best equilibrium with one zero is $v=(1,0)$ which gives the payoff less than the 2-element partition equilibrium.)

Similar for the case with two zeros.

For the last step, we show that there cannot be more than two voters 
with $v_{i}^{k}=(1,0)$ in $v^{k}$ for any element $M^{k}$ in a finer partition $\left\{M^{k}\right\}_{k=1}^{K} \leq\left\{M^{+}, M^{-}\right\}$. For any $M^{k} \subseteq M^{+}$, to have more than two voters with $(1,0)$ in $v$, there should exist some $a^{k}<b^{k}<c^{k}$ with $v_{a^{k}}^{k}=v_{b^{k}}^{k}=v_{c^{k}}^{k}=(1,0)$ such that

$$
E\left[\tilde{u}_{c^{k}} \mid M^{k}, \hat{S}_{c^{k}}\left(v_{-c^{k}}^{k}\right), s_{c^{k}}^{l}\right]<0 .
$$

Then, for any $k$,

$$
\begin{aligned}
& 0>E\left[\tilde{u}_{c^{k}} \mid M^{k}, \hat{s}_{c^{k}}\left(v_{-c^{k}}^{k}\right), s_{c^{k}}^{l}\right]=E\left[\tilde{u}_{c^{k}} \mid M^{k}, s_{a^{k}}^{h}, s_{b^{k}}^{h}, s_{c^{k}}^{l}\right] \\
& >E\left[\tilde{u}_{b^{k}} \mid M^{k}, s_{a^{k}}^{h}, s_{b^{k}}^{h}, s_{b^{k}}^{l}\right]=E\left[\tilde{u}_{b^{k}} \mid M^{k}, s_{a^{k}}^{h}\right] \\
& >E\left[\tilde{u}_{a^{k}} \mid M^{k}, s_{a^{k}}^{h}\right]>E\left[\tilde{u}_{1} \mid M^{k}, s_{1}^{h}\right] .
\end{aligned}
$$

This is a contradiction since

$$
E\left[\tilde{u}_{1} \mid M^{+}, s_{1}^{h}\right]=\sum_{k} \operatorname{Pr}\left[M^{k}, s_{1}^{h} \mid M^{+}, s_{1}^{h}\right] E\left[\tilde{u}_{1} \mid M^{k}, s_{1}^{h}\right]>0 .
$$

So, there should be no more than two zeros in an equilibrium voting strategy, $v$. 


\section{전문가의 전략적 정보전달이 의사결정자의 의견 형성에 미치는 영향}

정대영*

본고는 상대적 정보 우위를 가진 외부 전문가가 전략적 정보 전달을 통하여 집 단적 의사결정자들을 자신이 원하는 방향으로 설득하는 과정을 분석하였다. 모형 에서는 상대적 정보 우위를 가진 외부 전문가가 다양한 선호를 가진 집단적 의사 결정자들에게 칩톡(Cheap Talk)을 통해 정보를 전달하고, 의사결정자들은 외부 전문가가 제공하는 정보를 관찰한 후 투표를 통하여 주어진 사안의 가부를 결정하 도록 설정하였다. 모형 분석 결과, 외부 전문가는 단순한 정보전달 전략을 취함으 로써 의사결정자들을 양극화 또는 통합하여 그들을 효과적으로 설득해 낼 수 있다 는 결론을 얻었다. 또한, 외부 전문가의 정보 우위 정도가 충분히 클 경우, 의사결 정자들은 외부 전문가가 편향된 선호를 가지고 있다는 것을 알고 있음에도 불구하 고, 외부 전문가의 조언에만 의존하여 투표를 한다는 결론을 내릴 수 있다.

핵심 주제어: 칩톡, 투표제도, 양극화

J EL Classification: D71, D72, D78, D82, D83

* 한국은행 경제연구원 미시제도연구실 부연구위원 (전화: 02-759-5430, E-mail: daeyoung.jeong@bok.or.kr) 본 연구내용은 집필자의 개인의견이며 한국은행의 공식견해와는 무관합니다. 따라서 본 논문의 내용을 보도하거나 인용할 경우에는 집필자명을 반드시 명시하여 주시기 바랍니다. 


\section{$\mathrm{BOK}$ 경제연구 발간목록}

한국은행 경제연구원에서는 Working Paper인 『BOK 경제연구』를 수시로 발간하고 있습니다. ${ }^{\circledR} \mathrm{BOK}$ 경제연구』는 주요 경제 현상 및 정책 효과에 대한 직관적 설명 뿐 아니라 깊이 있는 이론 또는 실증 분석을 제공함으로써 엄밀한 논증에 초점을 두는 학술논문 형태의 연구이며 한국은행 직원 및 한국은행 연구용역사업의 연구 결과물이 수록되고 있습니다.

『BOK 경제연구』 는 한국은행 경제연구원 홈페이지(http://imer.bok.or.kr)에서 다운로드하여 보실 수 있습니다.

제2014-1 Network Indicators for Monitoring Intraday Liquidity in BOK-Wire+

2 중소기업에 대한 신용정책 효과

3 경제충격 효과의 산업간 공행성 분석

4 서비스업 발전을 통한 내외수 균형성장: 기대효과 및 리스크

5 Cross-country-heterogeneous and Time-varying Effects of Unconventional Monetary Policies in AEs on Portfolio Inflows to EMEs

6 인터넷뱅킹, 결제성예금 및 은행 수익성과의 관계 분석

7 Dissecting Foreign Bank Lending Behavior During the 2008-2009 Crisis

8 The Impact of Foreign Banks on Monetary Policy Transmission during the Global Financial Crisis of 2008-2009: Evidence from Korea

9 Welfare Cost of Business Cycles in Economies with Individual Consumption Risk

10 Investor Trading Behavior Around the Time of Geopolitical Risk Events: Evidence from South Korea

11 Imported-Inputs Channel of Exchange Rate Pass-Through: Evidence from Korean Firm-Level Pricing Survey
Seungjin Baek

Kimmo Soram ki • Jaeho Yoon

정호성·임호성

황선웅·민성환 ·

신동현 · 김기호

김승원 · 황광명

Kyoungsoo Yoon •

Christophe Hurlin

이동규·전봉걸

Moon Jung Choi •

Eva Gutierrez •

Maria Soledad Martinez Peria

Bang Nam Jeon •

Hosung Lim $\cdot \mathrm{Ji} \mathrm{Wu}$

Martin Ellison •

Thomas J. Sargent

Young Han Kim •

Hosung Jung

Jae Bin Ahn •

Chang-Gui Park 


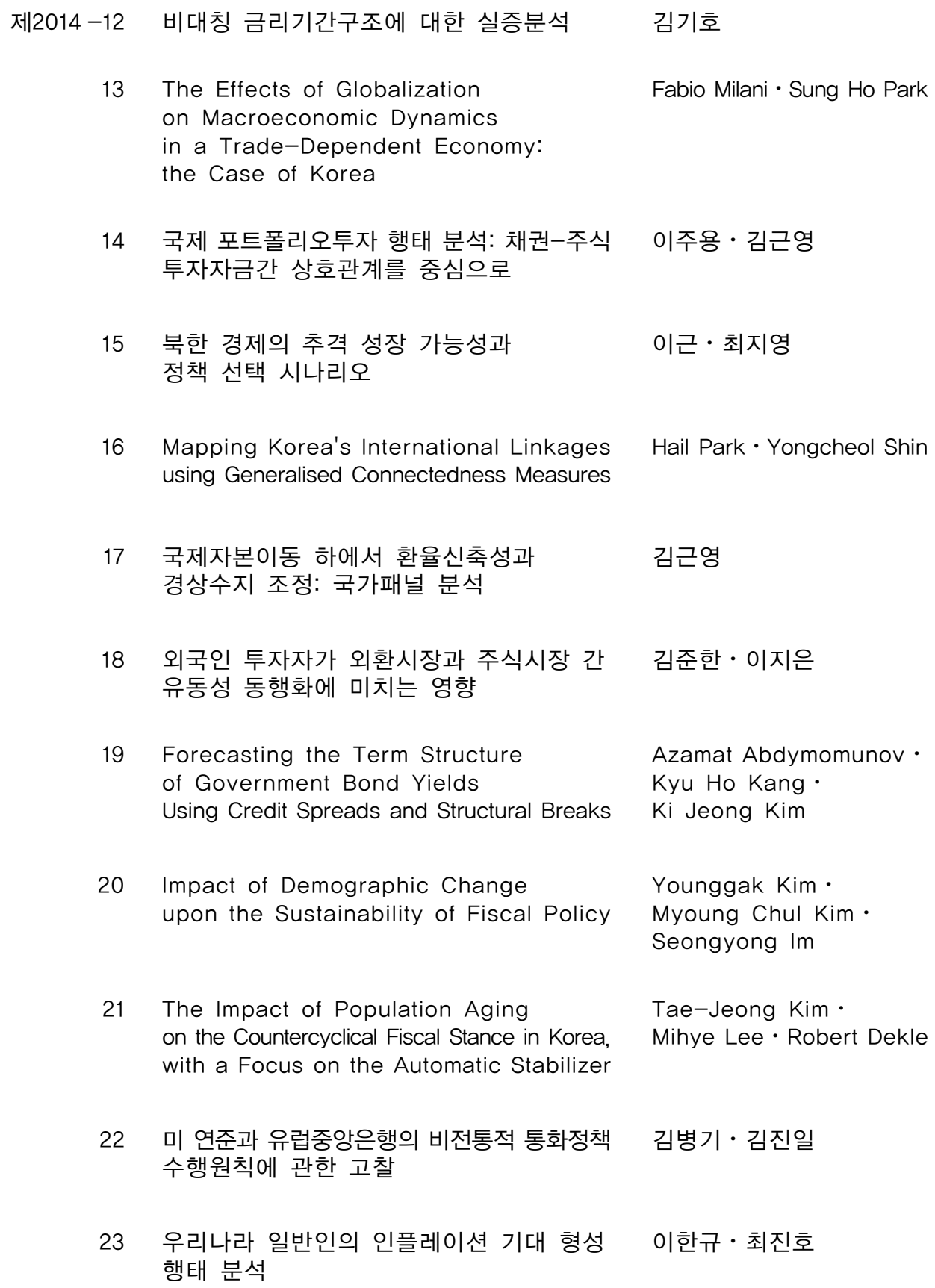

16 Mapping Korea's International Linkages using Generalised Connectedness Measures

17 국제자본이동 하에서 환율신축성과 경상수지 조정: 국가패널 분석

이주용·김근영

이근·최지영

Hail Park $\cdot$ Yongcheol Shin

18 외국인 투자자가 외환시장과 주식시장 간 유동성 동행화에 미치는 영향

19 Forecasting the Term Structure of Government Bond Yields Using Credit Spreads and Structural Breaks

20 Impact of Demographic Change upon the Sustainability of Fiscal Policy

21 The Impact of Population Aging on the Countercyclical Fiscal Stance in Korea, with a Focus on the Automatic Stabilizer

김근영

김준한 $\cdot$ 이지은

Azamat Abdymomunov •

Kyu Ho Kang.

Ki Jeong Kim

Younggak Kim •

Myoung Chul Kim.

Seongyong Im

Tae-Jeong Kim $\cdot$

Mihye Lee $\cdot$ Robert Dekle

22 미 연준과 유럽중앙은행의 비전통적 통화정책 수행원칙에 관한 고찰

김병기·김진일

23 우리나라 일반인의 인플레이션 기대 형성 행태 분석

이한규・최진호 
제2014-24 Nonlinearity in Nexus between

Working Hours and Productivity

25 Strategies for Reforming Korea's Labor Market to Foster Growth

26 글로벌 금융위기 이후 성장잠재력 확충: 2014 한국은행 국제컨퍼런스 결과보고서

27 인구구조 변화가 경제성장률에 미치는 영향: 자본이동의 역할에 대한 논의를 중심으로

28 Safe Assets

29 확장된 실업지표를 이용한 우리나라 노동시장에서의 이력현상 분석

Entropy of Global Financial Linkages

31 International Currencies Past, Present and Future: Two Views from Economic History

32 금융체제 이행 및 통합 사례:

남북한 금융통합에 대한 시사점

Measuring Price-Level Uncertainty and Instability in the U.S., 1850-2012

고용보호제도가 노동시장 이원화

및 노동생산성에 미치는 영향

35 해외충격시 외화예금의 역할 : 주요 신흥국 신용스프레드에 미치는 영향을 중심으로 Emerging Market Economies, and Their Policy Responses
Dongyeol Lee •

Hyunjoon Lim

Mai Dao · Davide Furceri ·

Jisoo Hwang .

Meeyeon Kim •

Tae-Jeong Kim

한국은행 경제연구원

손종칠

Robert J. Barro

김현학 · 황광명

Daeyup Lee

Barry Eichengreen

김병연

Timothy Cogley •

Thomas J. Sargent

김승원

정호성 - 우준명

김인수 · 이명수

황광명 · 김경민 ·

노충식·김미진

Woon Gyu Choi •

Taesu Kang •

Geun-Young Kim •

Byongju Lee 
제2015-1 글로벌 금융위기 이후 주요국

통화정책 운영체계의 변화

2 미국 장기시장금리 변동이 우리나라 금리기간구조에 미치는 영향 분석 및 정책적 시사점

3 직간접 무역연계성을 통한 해외충격의 우리나라 수출입 파급효과 분석

4 통화정책 효과의 지역적 차이

5 수입중간재의 비용효과를 고려한 환율변동과 수출가격 간의 관계

6 중앙은행의 정책금리 발표가 주식시장 유동성에 미치는 영향

7 은행 건전성지표의 변동요인과 거시건전성 규제의 영향

8 Price Discovery and Foreign Participation in The Republic of Korea's Government Bond Futures and Cash Markets

9 규제가 노동생산성에 미치는 영향:

한국의 산업패널 자료를 이용한 실증분석

10 인구 고령화와 정년연장 연구

(세대 간 중첩모형(OLG)을 이용한 정량 분석)

11 예측조합 및 밀도함수에 의한 소비자물가 상승률 전망

12 인플레이션 동학과 통화정책

13 Failure Risk and the Cross-Section of Hedge Fund Returns

14 Global Liquidity and Commodity Prices

15 Foreign Ownership, Legal System and Stock Market Liquidity
김병기·김인수

강규호·오형석

최문정·김근영

김기호

김경민

이지은

강종구

Jaehun Choi - Hosung Lim •

Rogelio Jr. Mercado •

Cyn-Young Park

이동렬 - 최종일 - 이종한

홍재화 - 강태수

김현학

우준명

Jung-Min Kim

Hyunju Kang ·

Bok-Keun $\mathrm{Yu}$.

Jongmin $\mathrm{Yu}$

Jieun Lee $\cdot$ Kee H. Chung 
제2015-16 바젤피 은행 경기대응완충자본 규제의 기준지표에 대한 연구

17 우리나라 대출 수요와 공급의 변동요인 분석

18 북한 인구구조의 변화 추이와 시사점

19 Entry of Non-financial Firms and Competition in the Retail Payments Market

20 Monetary Policy Regime Change and Regional Inflation Dynamics: Looking through the Lens of Sector-Level Data for Korea

21 Costs of Foreign Capital Flows in Emerging Market Economies: Unexpected Economic Growth and Increased Financial Market Volatility

22 글로벌 금리 정상화와 통화정책 과제: 2015년 한국은행 국제컨퍼런스 결과보고서

23 The Effects of Global Liquidity on Global Imbalances

24 실물경기를 고려한 내재 유동성 측정

25 Deflation and Monetary Policy

26 Macroeconomic Shocks and Dynamics of Labor Markets in Korea

27 Reference Rates and Monetary Policy Effectiveness in Korea

29 An Analysis of Trade Patterns in East Asia and the Effects of the Real Exchange Rate Movements

30 Forecasting Financial Stress Indices in Korea: A Factor Model Approach
서현덕·이정연

강종구 · 임호성

최지영

Jooyong Jun

Chi-Young Choi •

Joo Yong Lee

Roisin O'Sullivan

Kyoungsoo Yoon • Jayoung Kim

한국은행 경제연구원

Marie-Louise DJIGBENOU-KRE •

Hail Park

우준명·이지은

Barry Eichengreen

Tae Bong Kim •

Hangyu Lee

Heung Soon Jung •

Dong Jin Lee.

Tae Hyo Gwon .

Se Jin Yun

Bongseok Choi •

Wooyoung Park.

Bok-Keun Yu

Moon Jung Choi

Geun-Young Kim • Joo Yong Lee

Hyeongwoo Kim $\cdot$ Hyun Hak Kim. Wen Shi 


\begin{tabular}{|c|c|c|}
\hline 제2016 -1 & $\begin{array}{l}\text { The Spillover Effects of U.S. Monetary } \\
\text { Policy on Emerging Market Economies: } \\
\text { Breaks, Asymmetries and Fundamentals }\end{array}$ & $\begin{array}{l}\text { Geun-Young Kim } \cdot \\
\text { Hail Park } \\
\text { Peter Tillmann }\end{array}$ \\
\hline 2 & $\begin{array}{l}\text { Pass-Through of Imported Input Prices } \\
\text { to Domestic Producer Prices: Evidence } \\
\text { from Sector-Level Data }\end{array}$ & $\begin{array}{l}\text { JaeBin Ahn } \\
\text { Chang-Gui Park } \\
\text { Chanho Park }\end{array}$ \\
\hline 3 & $\begin{array}{l}\text { Spillovers from U.S. Unconventional } \\
\text { Monetary Policy and Its Normalization } \\
\text { to Emerging Markets: A Capital Flow } \\
\text { Perspective }\end{array}$ & $\begin{array}{l}\text { Sangwon Suh } \\
\text { Byung-Soo Koo }\end{array}$ \\
\hline 4 & $\begin{array}{l}\text { Stock Returns and Mutual Fund Flows } \\
\text { in the Korean Financial Market: } \\
\text { A System Approach }\end{array}$ & $\begin{array}{l}\text { Jaebeom Kim } \\
\text { Jung-Min Kim }\end{array}$ \\
\hline 5 & $\begin{array}{l}\text { 정책금리 변동이 성별·세대별 고용률에 } \\
\text { 미치는 영향 }\end{array}$ & 정성엽 \\
\hline 6 & $\begin{array}{l}\text { From Firm-level Imports to } \\
\text { Aggregate Productivity: Evidence } \\
\text { from Korean Manufacturing Firms Data }\end{array}$ & $\begin{array}{l}\text { JaeBin Ahn } \\
\text { Moon Jung Choi }\end{array}$ \\
\hline 7 & $\begin{array}{l}\text { 자유무역협정(FTA)이 한국 기업의 } \\
\text { 기업내 무역에 미친 효과 }\end{array}$ & 전봉걸·김은숙·이주용 \\
\hline 8 & $\begin{array}{l}\text { The Relation Between Monetary and } \\
\text { Macroprudential Policy }\end{array}$ & Jong Ku Kang \\
\hline 9 & $\begin{array}{l}\text { 조세피난처 투자자가 투자 기업 및 주식 } \\
\text { 시장에 미치는 영향 }\end{array}$ & 정호성·김순호 \\
\hline 10 & $\begin{array}{l}\text { 주택실거래 자료를 이용한 주택부문 거시 } \\
\text { 건전성 정책 효과 분석 }\end{array}$ & 정호성·이지은 \\
\hline 11 & $\begin{array}{l}\text { Does Intra-Regional Trade Matter in } \\
\text { Regional Stock Markets?: New } \\
\text { Evidence from Asia-Pacific Region }\end{array}$ & $\begin{array}{l}\text { Sei-Wan Kim } \\
\text { Moon Jung Choi }\end{array}$ \\
\hline 12 & $\begin{array}{l}\text { Liability, Information, and Anti-fraud } \\
\text { Investment in a Layered Retail } \\
\text { Payment Structure }\end{array}$ & $\begin{array}{l}\text { Kyoung-Soo Yoon } \\
\text { Jooyong Jun }\end{array}$ \\
\hline 13 & $\begin{array}{l}\text { Testing the Labor Market Dualism in } \\
\text { Korea }\end{array}$ & $\begin{array}{l}\text { Sungyup Chung } \\
\text { Sunyoung Jung }\end{array}$ \\
\hline 14 & $\begin{array}{l}\text { 북한 이중경제 사회계정행렬 추정을 통한 } \\
\text { 비공식부문 분석 }\end{array}$ & 최지영 \\
\hline
\end{tabular}




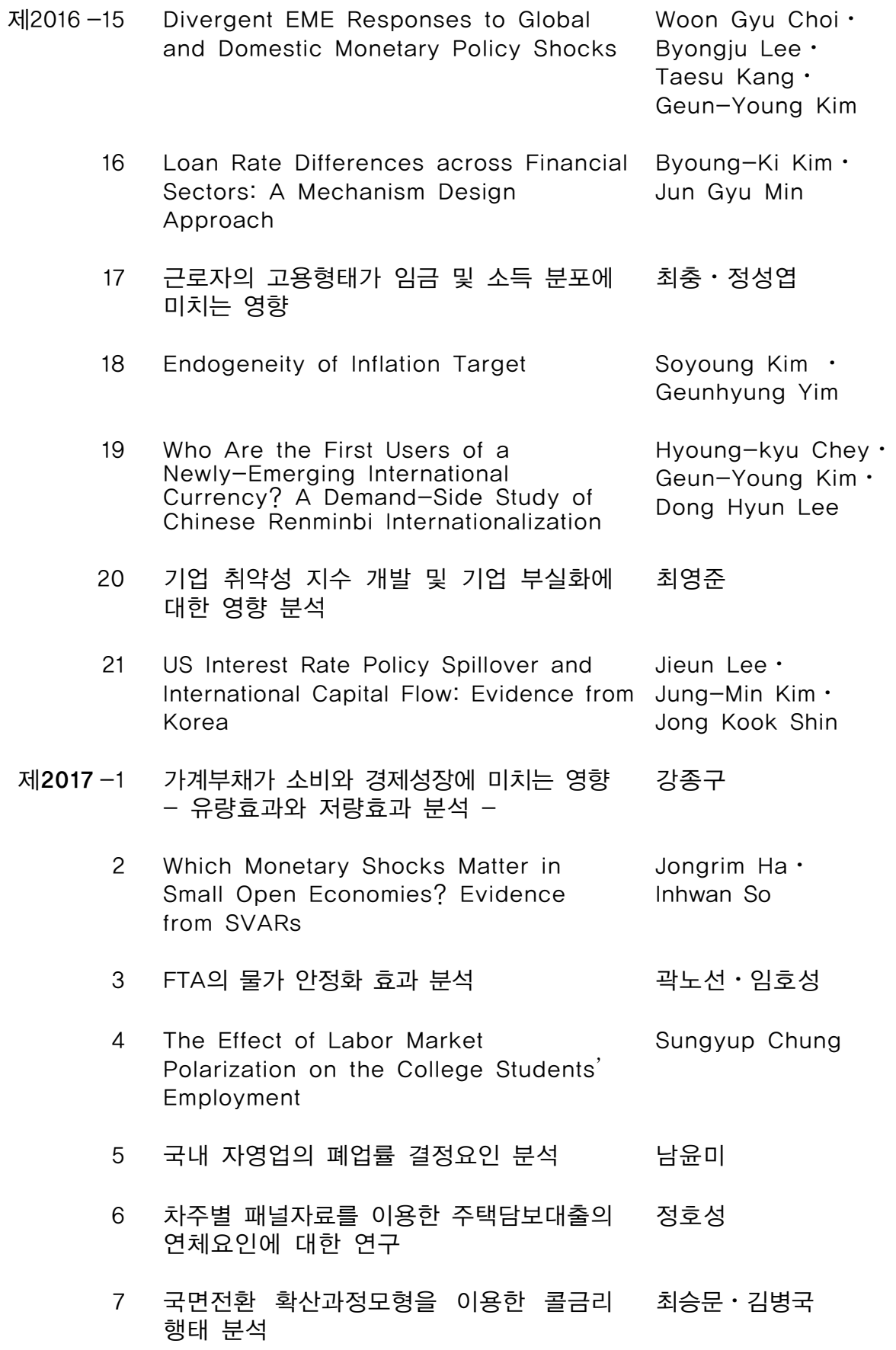

20 기업 취약성 지수 개발 및 기업 부실화에 최영준 대한 영향 분석

21 US Interest Rate Policy Spillover and Jieun Lee • International Capital Flow: Evidence from Jung-Min Kim • Korea Jong Kook Shin

제2017-1 가계부채가 소비와 경제성장에 미치는 영향 강종구

- 유량효과와 저량효과 분석 -

2 Which Monetary Shocks Matter in Small Open Economies? Evidence from SVARs

Jongrim $\mathrm{Ha} \cdot$ Inhwan So

3 FTA의 물가 안정화 효과 분석

곽노선·임호성

4 The Effect of Labor Market Polarization on the College Students'

Sungyup Chung Employment

5 국내 자영업의 폐업률 결정요인 분석 남윤미

6 차주별 패널자료를 이용한 주택담보대출의 정호성 연체요인에 대한 연구

7 국면전환 확산과정모형을 이용한 콜금리 최승문·김병국 행태 분석 


\begin{tabular}{|c|c|c|}
\hline 제2017 -8 & $\begin{array}{l}\text { Behavioral Aspects of Household } \\
\text { Portfolio Choice: Effects of Loss } \\
\text { Aversion on Life Insurance Uptake } \\
\text { and Savings }\end{array}$ & In Do Hwang \\
\hline 9 & 신용공급 충격이 재화별 소비에 미치는 영향 & 김광환·최석기 \\
\hline 10 & 유가가 손익분기인플레이션에 미치는 영향 & 김진용·김준철·임형준 \\
\hline 11 & $\begin{array}{l}\text { 인구구조변화가 인플레이션의 장기 } \\
\text { 추세에 미치는 영향 }\end{array}$ & 강환구 \\
\hline 12 & $\begin{array}{l}\text { 종합적 상환여건을 반영한 과다부채 } \\
\text { 가계의 리스크 요인 분석 }\end{array}$ & 이동진 · 한진현 \\
\hline 13 & $\begin{array}{l}\text { Crowding out in a Dual Currency Regime? } \\
\text { Digital versus Fiat Currency }\end{array}$ & $\begin{array}{l}\text { KiHoon Hong } \cdot \\
\text { Kyounghoon Park } \\
\text { Jongmin Yu }\end{array}$ \\
\hline 14 & $\begin{array}{l}\text { Improving Forecast Accuracy of } \\
\text { Financial Vulnerability: Partial Least } \\
\text { Squares Factor Model Approach }\end{array}$ & $\begin{array}{l}\text { Hyeongwoo Kim. } \\
\text { Kyunghwan Ko }\end{array}$ \\
\hline 15 & $\begin{array}{l}\text { Which Type of Trust Matters?: } \\
\text { Interpersonal vs. Institutional vs. } \\
\text { Political Trust }\end{array}$ & In Do Hwang \\
\hline 16 & 기업특성에 따른 연령별 고용행태 분석 & 이상욱·권철우·남윤미 \\
\hline 17 & $\begin{array}{l}\text { Equity Market Globalization and } \\
\text { Portfolio Rebalancing }\end{array}$ & $\begin{array}{l}\text { Kyungkeun Kim } \\
\text { Dongwon Lee }\end{array}$ \\
\hline 18 & $\begin{array}{l}\text { The Effect of Market Volatility on } \\
\text { Liquidity and Stock Returns in the } \\
\text { Korean Stock Market }\end{array}$ & Jieun Lee $\cdot \mathrm{KeeH}$.Chung \\
\hline 19 & $\begin{array}{l}\text { Using Cheap Talk to Polarize or Unify } \\
\text { a Group of Decision Makers }\end{array}$ & Daeyoung Jeong \\
\hline
\end{tabular}

